\title{
Dynamics of surface urban biophysical compositions and its impact on land surface thermal field
}

\author{
K. A. Ishola ${ }^{1}$ E. C. Okogbue ${ }^{1}$ O. E. Adeyeri ${ }^{1}$
}

Received: 5 August 2016/ Accepted: 24 November 2016 / Published online: 9 December 2016

(C) Springer International Publishing Switzerland 2016

\begin{abstract}
Urban heat effects over Abeokuta city, Nigeria have raised interests by relevant scientific communities owing to the recent infrastructural and economic growth of the area. In this paper, the surface temperatures and land surface biophysical types retrieved from Landsat TM, and ETM+images of Abeokuta city for 1984, 2003 and 2014 were analyzed. The images acquired were classified into appropriate land cover types using supervised classification schemes and a change detection analysis was carried out on the classified imageries using land change modeller (LCM) to evaluate the extent of modification of surface features. A quantitative approach was used to explore the relationships among temperature, surface biophysical components and spectral indices. Results showed that impervious surface and water areas were found to be correlated positively with high temperatures. Conversely, vegetated areas and bare surfaces correlated positively with mid temperature zones. The overall metrics error between the regression-modeled LST and the retrieved LST for the study area is quite low, between $2.63^{\circ} \mathrm{C}$ for root mean square error (RMSE) and $2.17^{\circ} \mathrm{C}$ for mean absolute error (MAE). This study concluded that, areas with increasing built-up surfaces and surface reflectivity will bring about LST rise, and consequently leads to urban heat island development.
\end{abstract}

Keywords Surface biophysical components $\cdot$ Spectral indices $\cdot$ Shortwave surface reflectivity $\cdot$ Land surface temperature $\cdot$ Surface thermal response

K. A. Ishola

skorchie126@yahoo.com

1 Department of Meteorology and Climate Science, Federal University of Technology, P.M.B. 704, Akure, Nigeria

\section{Introduction}

Urbanization has been on the increasing rate globally which could be attributed to the demand for space as a result of population and economic growth in the cities, and this is likely to continue in the subsequent decades (UN 2006). The process of urbanization modifies the natural landscape into anthropogenic surfaces which are land covers with buildings, roads, parking lots, and other paved surfaces. The amount of artificial surfaces is an important indicator of urban environmental quality. In the process, a direct environmental implication is the modification of land surfaces. That is, a large amount of natural lands have been, or will be transformed to various developed lands (e.g. commercial, industrial, transportation, and residential lands) within which impervious surfaces are a major composition. Consequently, the conversion results in the alteration of physical properties of land surfaces, including soil moisture, material heat capacity, conductivity, surface reflectivity and emissivity, etc., which leads to the decrease of evapotranspiration (Shoshany et al. 1994; Friedl 2002; Chudnovsky 2004). As a result, one of the most significant environmental impacts is the change of urban land surface temperature (LST) and atmospheric temperature, which significantly affects urban internal microclimatology, surface energy change, anthropogenic heat discharge, building energy consumption, atmospheric pollution, and human thermal comfort (Voogt and Oke 2003; Lu and Weng 2006; Sarrat et al. 2006).

Furthermore, the climate in and around cities and other built up areas is altered due to changes in Landuse/Landcover (LU/LC) and anthropogenic activities of urbanization. The most imperative problem in urban areas is increasing surface temperature thus, Land surface temperature can provide important information about the surface physical 
properties and climate which plays a role in many environmental processes (Dousset and Gourmelon 2003; Weng et al. 2004). Urban-Rural surface temperature variation observed at a large scale has been extensively documented in a number of studies since the 1970s (Chandler 1976; Oke 1982; Quattrochi and Pelletier 1991). For instance, Yuan and Bauer (2007) established a strong linear relationship between LST and percent impervious surface for all seasons over Minnesota, whereas the relationship between LST and NDVI is much less strong and varies by season. The study suggested percent impervious surface provides a complementary metric to the traditionally applied NDVI for analyzing LST quantitatively over the seasons for surface urban heat island studies using thermal infrared remote sensing in an urbanized environment, and adopting urban greening as means of ameliorating the impending urban heat effects. Similar study over Abuja, Nigeria also confirmed strong correlations between high surface temperature and negative NDV1 values (Musa et al. 2012). Moreover, the percentage density of biophysical factors can as well quantitatively influence urban surface temperature. The percentage of low density built- up, high density built-up, extremely-high buildings, low buildings per grid cell, and population density positively related with LST, but was negatively correlated with the percentage of forest, farmland, and water bodies per grid cell (Xiao et al. 2007). The use of multi-temporal satellite data together with the examination of changes in the temperature-vegetation index (TVX) space was suggested to be effective and useful in urban LULC monitoring and analysis of urban surface temperature conditions (Zemba 2010). Furthermore, the shortwave surface reflectivity is an important surface component that can influence LST. Ibrahim et al. (2012) found highest mean temperature with the highest albedo and impervious surface but inversed to NDVI over Kuala Lumpur. Based on spectral indices, NDVI and Normalized Difference Water Index (NDWI) had low influence $(r<0.5)$ with temperature and relatively moderate correlation between the Normalized Difference Built-up Index (NDBI) and temperature (Igor and Bastos 2012). In other approach, Wu et al. (2012) has established that spectral un-mixing and thermal mixing (SUTM) outperforms other regression models with normalized difference vegetation index NDVI, percent green vegetation $(\% \mathrm{GV})$ and percent impervious surface area (\%ISA) as individual independent variables, with the lowest root mean square error $(\mathrm{RMSE}=2.89 \mathrm{~K})$ and mean absolute error $(2.11 \mathrm{~K})$.

Satellite remote sensing is an important data source for monitoring, detection, quantification, and mapping of land cover patterns and changes, because of its large spatial coverage, repetitive data acquisition, digital format appropriate for computer processing, and accurate georeferencing approaches (Jennings 2000; Kerr and Ostrovsky
2003; Rogan and Miller 2006; Pellikka et al. 2009; Loveland and Dwyer 2012). The advent of geographic information system (GIS) has also made it possible to integrate multisource and multitemporal data for the generation of changes in land surface components involving such information as the trend, rate, nature, location and magnitude of the changes (Adeniyi and Omojola 1999). Urban heat effects over Abeokuta, Nigeria have raised interests by relevant scientific communities owing to the recent infrastructural and economic growth of the area. However, our understanding and scientific confidence in the changes in the urban heat phenomenon associated with changes in urban surface components have been limited in this area. That is, availability and accessibility of accurate, reliable and current representation of urban surface components are the major identified gaps, particularly in Abeokuta city. Therefore, this work quantitatively assessed the changes in status of urban surface characteristics and the impacts on the thermal environment of Abeokuta city, Nigeria using remote sensing and GIS techniques.

\section{Materials and methods}

\section{Materials and study area}

This study looks at the city of Abeokuta the capital of Ogun State in the southwest, Nigeria (Fig. 1) due to its rapid human and industrial growth and development. It lies between latitude $7^{\circ} 10^{\prime} \mathrm{N}$ and $7^{\circ} 15^{\prime} \mathrm{N}$ and longitudes $3^{\circ} 17^{\prime} \mathrm{E}$ and $3^{\circ} 26^{\prime} \mathrm{E}$. Annual rainfall is about $963 \mathrm{~mm}$ and the temperature is usually between 26 and $28^{\circ} \mathrm{C}$ (NiMET 2007). The study employs cloudless Landsat 5 TM for 18 Dec., 1984, and Landsat 7 ETM + for 29 Jan., 2003, and 29 Dec., 2014 (see Table 1). All imageries were obtained from the archives of United States Geological Survey (USGS). The three scenes fell within the path 191 and row 055 of the WRS-2 (Worldwide Reference System) from which the data for the location under study could be extracted. All bands from the images were applied in the analysis. The bands $1-5$ and 7 have a spatial resolution of $30 \mathrm{~m}$, and the thermal infrared band (band 6) has a spatial resolution of $60 \mathrm{~m}$ for Landsat 7 and $120 \mathrm{~m}$ for Landsat 5.

\section{Image processing}

The image pre-processing including geometric, atmospheric and topographic corrections were carried out in the Geographic Information System (GIS) environment to ensure spatial and temporal comparability of the datasets (Kaufman 1989). The radiometric correction employed the algorithm of Chander and Markham (2003) with the addition of an atmospheric correction. 


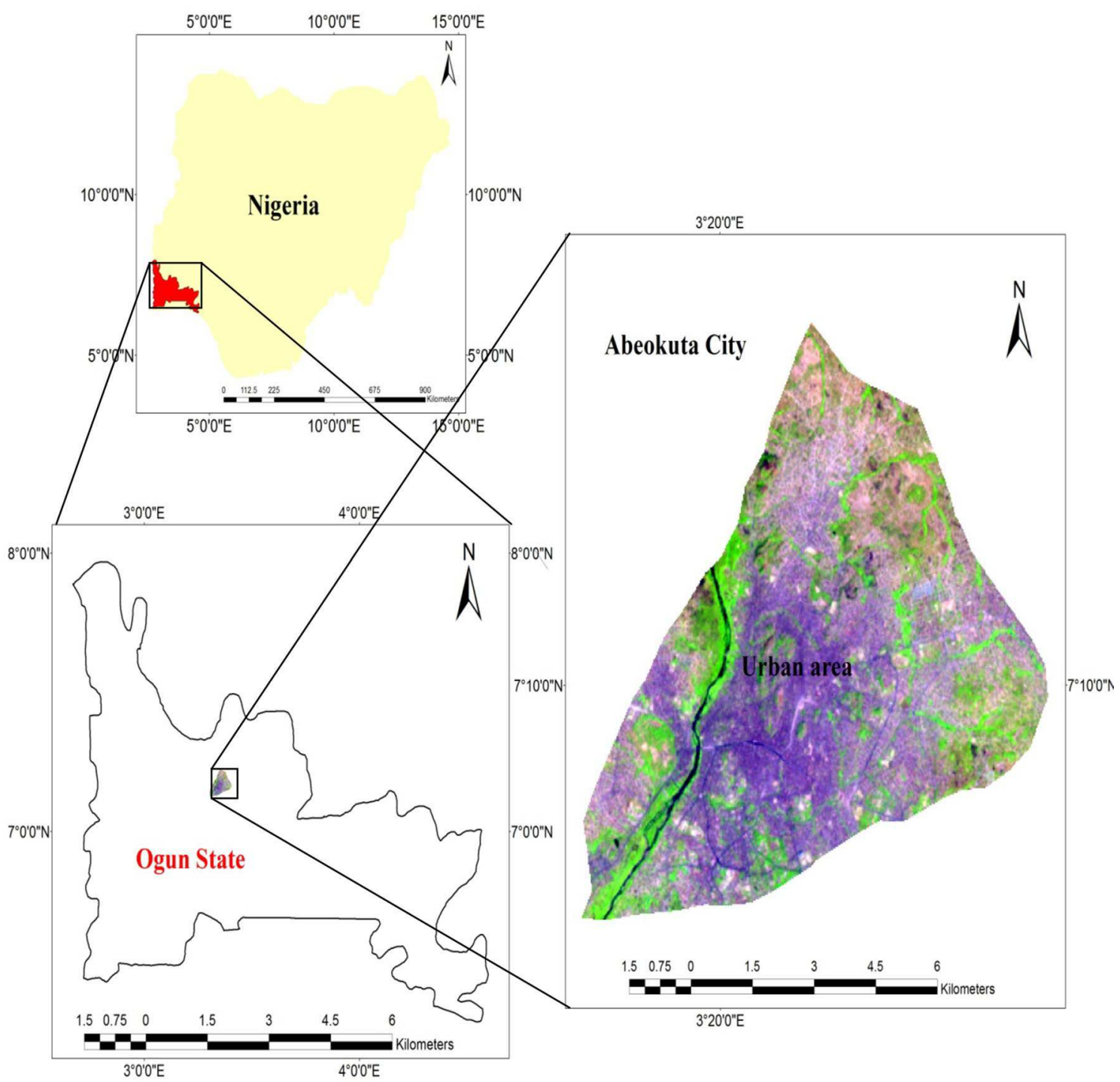

Fig. 1 Location of the study area

Table 1 Landsat metadata for the study area. (Source: USGS 2014)

\begin{tabular}{|c|c|c|c|c|c|c|c|}
\hline City & Path/row & Satellite platform & Band used & $\%$ cloud & Date acquired & Resolution & Source \\
\hline \multirow[t]{3}{*}{ Abeokuta } & $191 / 055$ & Landsat5 TM & $4,3,2$ and thermal band 6 & $0 \%$ & $18 / 12 / 1984$ & $30 \mathrm{~m} / 120 \mathrm{~m}$ & USGS \\
\hline & & Landsat7 ETM+ & $4,3,2$ and thermal band 6_1 & $1 \%$ & $29 / 01 / 2003$ & $30 \mathrm{~m} / 60 \mathrm{~m}$ & \\
\hline & & & & $0 \%$ & $29 / 12 / 2014$ & & \\
\hline
\end{tabular}

The three sets of images were first geo-corrected and geo-referenced because effective image processing is critical to successful urban surface component mapping and change analysis (Mussie 2011). The 2003 image was used as the base image for geometrical correction due to its better visual quality. Geometric correction of the 2003 scene was based on Ground Control Points (GCPs) identified on the topographical maps of the area. The 1984 and 2014 scenes were co-registered to the base image using additional GCPs into UTM projection with geometric errors of less than one pixel, so that all the images have the same coordinate system (Adedeji et al. 2015). The images were layer stacked accordingly by combining the required bands based on the satellite sensor to produce the appropriate color composite images, and subset to the area of study. 


\section{Image classifications}

Before any useful thematic information can be extracted from remote sensing data, a land cover classification system has to be developed to obtain the classes of interest to the analyst (Congalton 1991). Image classification refers to the extraction of differentiated land cover and land use categories classes from raw remotely sensed digital satellite data (Weng 2002). The imageries were classified based on sample set created according to training samples. Training samples are representative of the desired land use classes (Magidi 2010) and were determined based on ground truthing, researcher's personal experience and physiographical knowledge of the study area (Jensen 2007). Twenty (20) training samples were collected for each Landsat imagery used in this work and the Maximum Likelihood Classifier (Lillesland and Kiefer 1999) was used in performing supervised classification in the GIS environment. First, a chosen color composite (RGB $=432$ ) was used for digitizing polygons around each training sample for similar land cover. Then a unique identifier was assigned to each known land cover type. Afterwards, the statistical characterizations (i.e., signatures) of each land cover class were developed and a maximum likelihood classification method was used with equal priori probability for all classes. This procedure has proven to be a robust and consistent classifier for multidate classifications (Wu et al. 2006). Each composed image was ordered into 4 area classes: water, vegetation, impervious surface and bare soil as described in Table 2. The accuracy of the classified imageries was further evaluated using confusion/error matrices. This is an important method for evaluating per-pixel classification (Weng 2002).

\section{Change detection analysis}

To calculate the extent of each land cover class, we analysed classified maps using GIS tool. Change detection analysis was carried out on Landsat images of different years (i.e. 1984, 2003 and 2014) to analyze the pattern and trend of change analysis in the study area using Land Change Modeller (LCM) for ecological sustainability embedded in Idrisi (Eastman 2006). Land Change Modeller is innovative land planning and decision support software, which allows rapid analysis of land cover change and simulate future land change scenarios (Idirisi 2006; Deng et al. 2009; Mishra et al. 2011; Odindi et al. 2012). Using LCM requires mainly two time categorical maps and so the classified maps [say 1984 (time1) and 2003 (time-2)] were used as inputs for the Change Analysis. This enabled us to understand the gains and losses and the transition of areas among the land use/land cover classes; and to quantify the changes occurred from time- 1 to time-2 (Idirisi 2006).

\section{Computational methods}

The surface energy balance algorithms (SEBAL) provide the opportunity to estimate land surface temperature and several spectral indices from the satellite remotely sensed images (Ralf et al. 2002). Hence, developing digital database for the areas under investigation require the computational phases based on the modified SEBAL procedure (see Fig. 2).

The spectral radiance rescaling values was computed using the metadata file of each image. It was calculated using the algorithm below (Ralf et al. 2002):

$L_{\lambda}=\frac{\left(L_{\max \lambda}-L_{\min \lambda}\right)}{\left(Q_{c a l \max }-Q_{c a l \min }\right)} \times\left(Q_{c a l}-Q_{c a l \text { min }}\right)+L_{\min \lambda}$

where; $\mathrm{L}_{\lambda}=$ spectral radiance at the sensor's aperture (w/ $\mathrm{m}^{2}$ ster $\left.* \mu \mathrm{m}\right) ; \mathrm{Q}_{\text {cal }}=$ the quantized calibrated pixel value in $\mathrm{DN} ; \mathrm{L}_{\text {min }}=$ the spectral radiance scaled to $\mathrm{Q}_{\text {calmin }}(\mathrm{w} /$ $\mathrm{m}^{2}$ ster $\left.^{*} \mu \mathrm{m}\right) ; \mathrm{L}_{\max \lambda}=$ the spectral radiance scaled to $\mathrm{Q}_{\text {calmax }}\left(\mathrm{w} / \mathrm{m}^{2 *}\right.$ ster* $\left.\mu \mathrm{m}\right) ; \mathrm{Q}_{\text {calmin }}=$ the minimum quantized calibrated pixel value (corresponding to $\mathrm{L}_{\min \lambda}$ ) in $\mathrm{DN}=0$ or 1 (depends on the products and date processed); $\mathrm{Q}_{\text {CALMAX }}=$ the maximum quantized calibrated pixel value (corresponding to $\mathrm{L}_{\max \lambda}$ ) in $\mathrm{DN}=255$.

The spectral radiance retrieved from each landsat imagery was converted to planetary reflectance using Eq. 2 (Ralf et al. 2002):

$L_{\min \lambda}=\frac{(\pi \times L \lambda \times d 2)}{(E S U N \lambda \times \cos \theta s)}$

Table 2 Details of the land cover types

\begin{tabular}{ll}
\hline Land cover type & Description \\
\hline Impervious surface & $\begin{array}{l}\text { All infrastructure-residential, commercial, mixed use and industrial surface areas, asphalt road network, pavements, rocks, } \\
\text { parking lots, and other man-made structures } \\
\text { River, permanent open water, lakes, ponds, canals, permanent/seasonal wetlands, low-lying areas, marshy land, and swamps } \\
\text { Water body }\end{array}$ \\
$\begin{array}{l}\text { Trees, natural vegetation, mixed forest, gardens, parks and playgrounds, grassland, vegetated lands, agricultural lands, and } \\
\text { crop fields }\end{array}$ \\
$\begin{array}{l}\text { Fallow land, earth and sand land in-fillings, construction sites, developed land, excavation sites, open space, bare soils, and } \\
\text { the remaining land cover types }\end{array}$
\end{tabular}




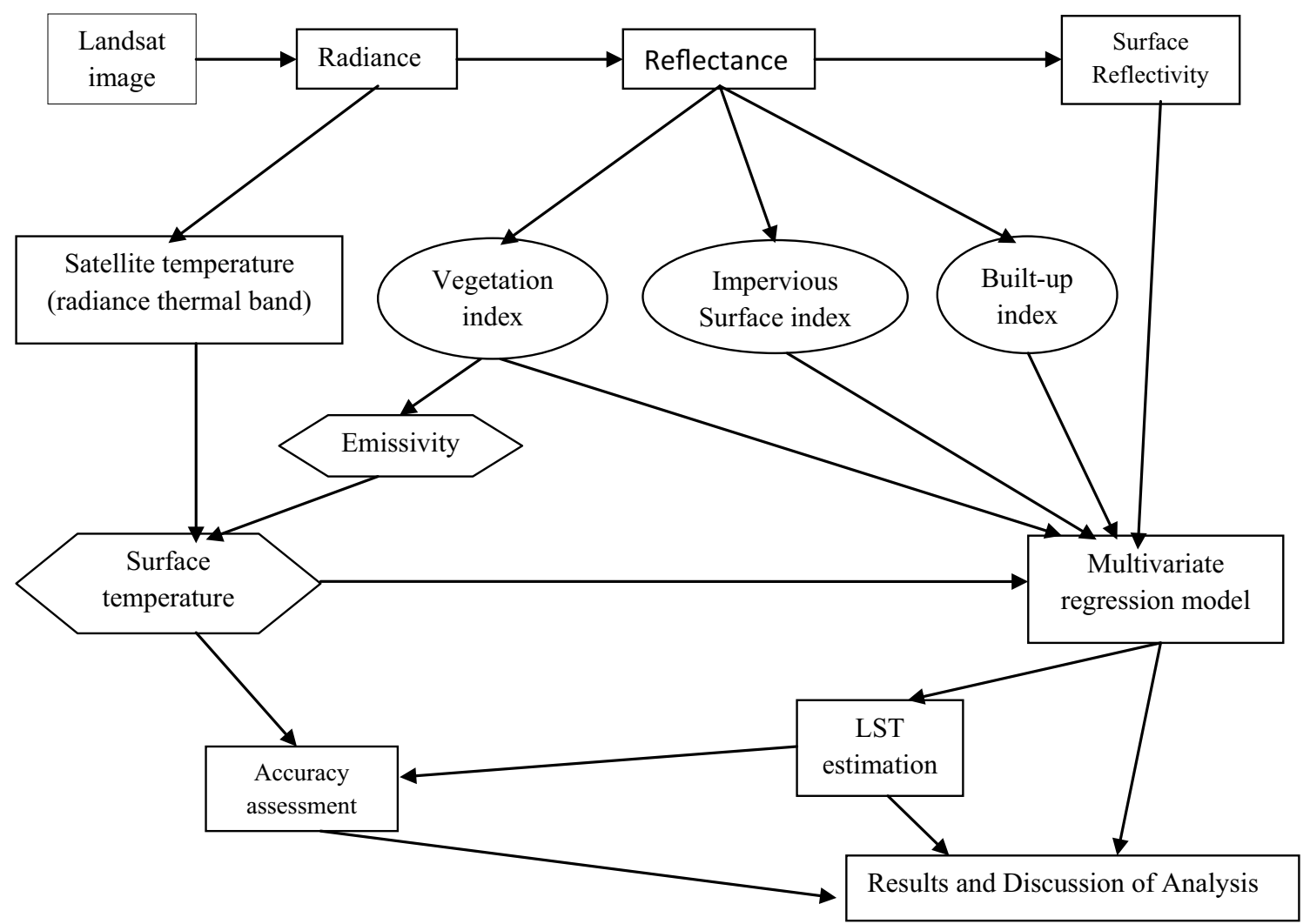

Fig. 2 Computational process for estimation of land surface temperature (modified after Ralf et al. 2002)

where; $\rho_{\lambda}=$ TOA planetary reflectance; $\mathrm{L}_{\lambda}=$ spectral radiance at the sensor's aperture $\left(\mathrm{w} / \mathrm{m}^{2 *}\right.$ ster $\left.^{*} \mu \mathrm{m}\right) \mathrm{d}=$ Earth-Sun distance in astronomical units; $\mathrm{ESUN}_{\lambda}=$ Mean solar exoatmospheric irradiances; $\theta_{\mathrm{s}}=$ solar zenith angle in degrees; $\theta_{\mathrm{s}}=90^{\circ}-\theta_{\mathrm{E}}$.

\section{Extraction of spectral indices from the landsat imageries}

The spectral indices NDVI (Jensen 2000), normalized difference impervious surface index (NDISI) (Xu 2010) and NDBI (Zha et al. 2003; Zhang et al. 2009; Zeng et al. 2010) were used to characterize the land cover types and quantify the relationships between land cover type and urban thermal effect.

The NDVI (Eq. 3) is a sensitive indicator of the amount and condition of green vegetation. Values for NDVI range between -1 and +1 . Green surfaces have a NDVI between 0 and 1, and water and cloud are usually less than zero (Ralf et al. 2002). The NDBI (Eq. 4) index was developed to analyze increments of reflectance on bands 4 and 5 for images of urbanized and barren land areas. It ranges between -1 to +1 (Zha et al. 2003). Moreover, the NDISI (Eq. 5) index is a measure of the imperviousness. The impervious surface features can be mixed with water noise (Xu 2010). However, using a water index (NDWI)-derived band can significantly suppress the water noise, as it can enlarge the contrast between water and impervious surface.

$N D V I=\frac{(\text { pand } 4-\rho \text { band } 3)}{(\text { pand } 4+\rho \text { band } 3)}$

$N D B I=\frac{(\text { pband } 5-\rho \text { band } 4)}{(\text { pand } 5+\rho \text { band } 4)}$

$N D I S I=\frac{\left[\rho \text { band } 6-\frac{N D W I+\rho \text { band } 4+\rho \text { band } 5}{3}\right]}{\left[\rho \text { band } 6+\frac{N D W I+\rho b a n d 4+\rho b a n d 5}{3}\right]}$

$N D W I=\frac{(\text { pband } 2-\rho \text { band } 4)}{(\text { band } 2+\rho \text { band } 4)}$

where;

pband2 reflectance digital number (DN) values for Green band for TM and ETM+

pband3 reflectance DN values for red band for TM and ETM+

pband4 reflectance DN values for Near-Infrared band for TM and ETM+ 
pband5 reflectance DN values for Shortwave Infrared band for TM and ETM+

pband6 reflectance DN values for thermal infrared band for TM and ETM+

\section{Extraction of shortwave surface reflectivity $\left(\alpha_{S S R}\right)$}

This is computed by correcting the albedo top of the atmosphere $\left(\alpha_{t o a}\right)$ for atmospheric transmissivity (Ralf et al. 2002):

$\alpha_{S S R}=\frac{\left(\alpha_{T O A}-\alpha_{r a d}\right)}{\left(\tau_{S W}^{2}\right)}$

$\tau_{S W}^{2}=0.75+2 \times 10^{-5} \times z$

where: $\quad \alpha_{\mathrm{SSR}}=$ shortwave surface reflectivity (SSR); $\alpha_{\text {toa }}=$ albedo top of the atmosphere; $\alpha_{\text {rad }}=$ path radiance $(0.025-0.04) ; \tau_{\mathrm{sw}}=$ shortwave atmospheric transmittance; $\mathrm{z}=$ elevation ASL (m).

Values for $\alpha_{\text {rad }}$ range between 0.025 and 0.04 (Tasumi et al. 2000) and a reasonable value of 0.03 is recommended (Bastiaanssen et al. 1998). The satellite reflectance for Landsat TM was converted directly to SSR while, Landsat ETM+required satellite reflectance to be changed to albedo top of the atmosphere for radiometric correction. The output was then converted to SSR for the period. The values of SSR vary over heterogeneous surfaces. The lowest value is estimated over deep water and highest over white sands (see Table 3) (Brutsaert 1982).

\section{Extraction of surface temperature}

The algorithm of Ralf et al. (2002) was employed to convert landsat raw image to at-satellite radiance (Eq. 1). Thermal band 6 was then converted to at-satellite temperature (Eq. 9), and then emissively (Eq. 10) corrected to LST (Eq. 11). The LST was retrieved using the following models;

Table 3 Range of SSR values for different landcover types (Brutsaert 1982)

\begin{tabular}{ll}
\hline Surface & SSR \\
\hline Moist dark soils & $0.05-0.15$ \\
Dry soils, deserts & $0.15-0.25$ \\
Gray soils, bare surface & $0.2-0.35$ \\
White sands, lime & $0.3-0.4$ \\
Coniferous forest & $0.10-0.15$ \\
Green grass and other short vegetation & $0.15-0.25$ \\
Deep water & $0.04-0.08$ \\
\hline
\end{tabular}

$$
\begin{aligned}
T_{b} & =\frac{K_{2}}{\ln \left[\left(K_{1} / L_{\lambda}\right)+1\right]} \\
\varepsilon_{0} & =1.009+0.047 \times \ln (N D V I)
\end{aligned}
$$

$$
L S T=\frac{T_{b}}{\varepsilon_{0}^{0.25}}
$$

where $\mathrm{T}_{\mathrm{b}}=$ brightness temperature $(\mathrm{K}) ; \mathrm{L}_{\lambda}=$ spectral radiance of thermal band $6\left(\mathrm{Wm}^{-2} \mathrm{sr}^{-1} \mu \mathrm{m}^{-1}\right)$;

$\mathrm{K}_{1}$ and $\mathrm{K}_{2}=$ calibration constants. $\mathrm{K}_{1}=607.76 / 666.09$ and $\mathrm{K}_{2}=1260.56 / 1282.71\left(\mathrm{Wm}^{-2} \mathrm{sr}^{-1} \mu \mathrm{m}^{-1}\right)$ for Landsat $5 / 7 . \varepsilon_{0}=$ Surface broad band emissivity.

All landsat imageries were processed and computed using the ERDAS imagine 9.1, IDRISI selva 17.00 and ArcGIS Desktop 10 (ESRI, 2012).

\section{Quantitative analysis}

First, land cover change statistics were computed as absolute percentage increments of the study area calculated by subtracting percentage areas among later time (t2) and former time (t1) (Adedeji et al. 2015).The negative symbol in the statistics indicated a loss of surface. The analysis of the influence of urban surface biophysical compositions on urban thermal environment was also carried out. This is achieved by investigating the quantitative contributions of land cover indices to LST change using multivariate regression analysis with a number of samples throughout whole image. The model equation (see Table 6) were obtained using surface temperature (LST) as predictant and the afore-mentioned parameters as predictors: normalized difference built-up index (NDBI), normalized difference impervious surface index (NDISI), normalized difference vegetation index (NDVI) and shortwave surface reflectivity (SSR) by cells. Although, SSR is not regarded as a normalized spectral index but, it is an important biophysical component that can also influence LST change over an area. Hence, the inclusion of the component as one of the landcover indices used in estimating LST over the study area. The method for the construction of model equations is the stepwise multiple regression. The applied implementation of this procedure is part of the R computer statistics software. Predictors were retained or removed from the model depending on the significance of the $F$ value of 0.01 and 0.05 , respectively. To evaluate the extent of the relationships between the urban surface temperature intensity and various urban surface factors, multiple correlation matrix and regression analyses were applied. The correlation matrices were processed using the $\mathrm{R}$ software environment for statistical computing (R Core Team, 2012). These correlations were coded in three ways: shape, numeric value, 
and colour. The ellipse shape at $45^{\circ}$ to the right shows perfect positive correlations and vice versa. For zero correlation, the shape becomes circle. To assess the accuracy of the LST estimates, two accuracy metrics, root mean square error (RMSE) and mean absolute error (MAE), were employed. These metrics can be expressed as follows.

$R M S E=\sqrt{\frac{1}{N}} \sum_{i=1}^{N}\left(L S T_{i}-\overline{L S T_{i}}\right)^{2}$

$M A E=\frac{1}{N} \sum_{i=1}^{N}\left|L S T_{i}-\overline{L S T}_{i}\right|$

where $\overline{L S T}_{i}$ is the estimated LST for pixel $i ; L S T_{i}$ is the actual LST of pixel $i$ retrieved from the Landsat thermal images; $\mathrm{N}$ is the total number of pixel samples of the Landsat images. Both RMSE and MAE are measures of precision, and quantify the relative estimation error at the pixel level. To investigate the performance of the regressionbased model with different degrees of urban development, those two error metrics were also calculated for the four land-cover types.

\section{Results and discussion}

\section{Classifications and dynamics of surface biophysical components}

The acquired satellite images $(1984,2003$, and 2014) were classified into four broad land cover types, as shown in Table 2. The results of the classifications of land cover are found in Fig. 3. The classified images were assessed for accuracy by comparing with the original landsat imageries based on a random selection of 200 reference pixels for each time period (Ahmed and Ahmed 2012). The overall accuracies of the classified images revealed $86.48 \%$ in $1984,88.02 \%$ in 2003 , and $91.13 \%$ in 2014. The Kappa coefficients were observed to be $0.86,0.88$, and 0.91 for 1984, 2003, and 2014 respectively (Table 4).

The land cover maps of Abeokuta area (Fig. 3) has shown a progressive increase in imperviousness and a corresponding decrease in the areas covered by vegetation and bare soil from 1984 to 2014. The impervious surface area has the largest proportion throughout the period from $50 \%$ in 1984 to $81 \%$ in 2014 (Fig. 4) due to more rock surfaces over the area while; water body has the lowest proportion of $1 \%$ of the total area covered. The implication was the reduction in the percentage area covered by vegetation and bare soil from $21 \%$ in 1984 to $8 \%$ in 2014, and $28 \%$ in 1984 to $8 \%$ in 2014 respectively due to the increasing socio-economic factors such as population, economic, technological and institutional growth. These factors have triggered competition for space for various urban development purposes such as residential, commercial, recreation, institutional, industrial, transportation thereby increasing impervious surface area and consequently decreasing vegetation and bare soil areas. Thus, it can be deduced that the impervious area will continually extend towards the sub-urban and rural areas if the increasing in the enumerated factors is sustained for the subsequent years. However, it is vague to understand the proportion of one land cover type that was converted to another and the extent of conversion from one category to the others. Further analyses were conducted to understand these patterns of conversion throughout the period of study.

The changes in land cover types as shown in Fig. 5 revealed that, about 9 and $2 \%$ percentage of area covered by impervious surface was loss to other land cover types between 1984-2003 and 2003-2014 respectively. In a long time change between 1984 and 2014, only about 4\% of impervious surface area was lost to other land cover types. This implies that few parts of existed impervious areas were modified into some other land cover types. However, a significant change occurred in the vegetation and bare soil categories in both periods. These land cover categories lost more land areas than they gained in each time period (Fig. 5).

The analyses on the net change in the areas covered by the land cover classes showed that, there was significant and progressive change (increased with magnitude $>5 \%$ ) in impervious areas in all the time periods (Fig. 6). The net change of bare soil and vegetation showed decrease in all the time periods.

The conversion patterns between the land cover categories were illustrated in Figs. 7, 8, and 9. It was observed that the bare soil was the major contributor to net change (increasing) in impervious surface areas followed by vegetation and no significant contribution from water body in all periods (Fig. 7).

More significant contributions to net change (increasing) in bare soil areas were seen from vegetation between 1984 and 2003, and in a long time period between 1984 and 2014 (Fig. 8). However, there were no places where either impervious surface or water body was converted to bare soil type at all.

In addition, Fig. 9 revealed that the water body is the major contributor to extending vegetated areas between 1984 and 2003. Although a few percentage of bare soil areas was modified to vegetation between 2003 and 2014 (Fig. 9a), there was no contributions to net change in vegetation in a long time period between 1984 and 2014 at all (Fig. 9c). These findings have established the patterns of land use/land cover changes (LULC), and the role of one land cover category in contributing to the net change in 


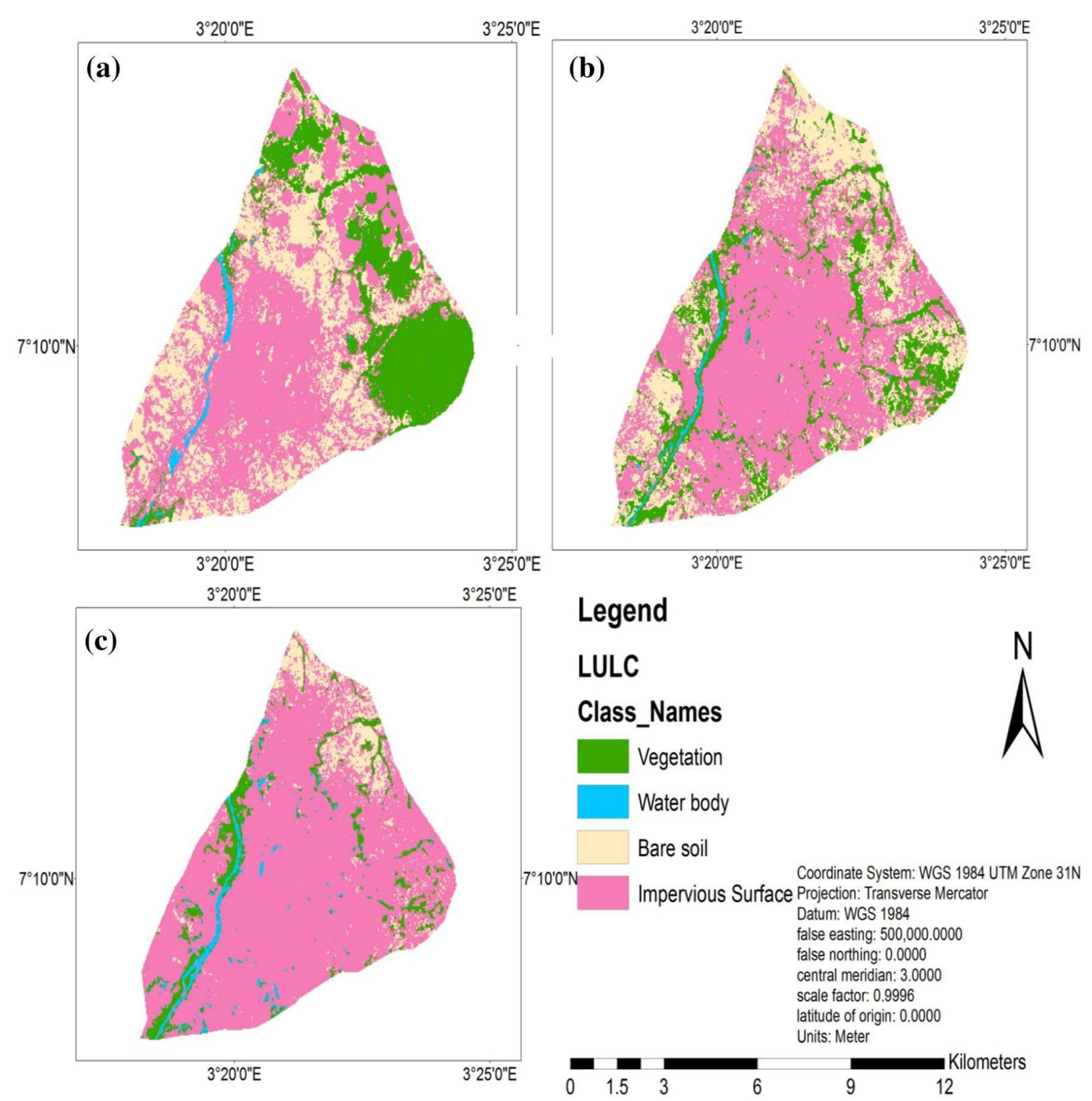

Fig. 3 Maps of surface biophysical classes of Abeokuta city for a 1984 b 2003 c 2014

Table 4 Accuracy assessments of the Land cover classes

\begin{tabular}{|c|c|c|c|c|c|c|c|c|c|c|}
\hline \multicolumn{5}{|c|}{ User's accuracy (\%) } & \multicolumn{4}{|c|}{ Producer's accuracy (\%) } & \multicolumn{2}{|l|}{ Overall } \\
\hline \multirow[t]{2}{*}{ Year } & Water & Vegetation & ISA & Bare & Water & Vegetation & ISA & Bare & Accuracy & Kappa \\
\hline & Body & & Area & Soil & Body & & Area & Soil & $(\%)$ & Coefiicient \\
\hline 1984 & 83.70 & 86.67 & 93.35 & 82.19 & 83.38 & 87.08 & 91.68 & 81.85 & 86.48 & 0.86 \\
\hline 2003 & 86.52 & 87.75 & 89.39 & 88.40 & 88.65 & 86.69 & 87.10 & 88.36 & 88.02 & 0.88 \\
\hline 2014 & 91.72 & 90.56 & 90.46 & 91.78 & 92.39 & 90.53 & 91.70 & 89.81 & 91.13 & 0.91 \\
\hline
\end{tabular}

another which is similar to the findings from Ahmed et al. (2013).

The land cover change dynamics over the area has shown that, a huge proportion of vegetated and bare soil areas were lost from 14.53 and $19.49 \mathrm{~km}^{2}$ in 1984 to $5.52 \mathrm{~km}^{2}$ and $5.30 \mathrm{~km}^{2}$ by 2014 respectively (Table 5 ). This is manifested in the tremendous increase in the proportion of impervious surface area from $34.84 \mathrm{~km}^{2}$ in 1984 


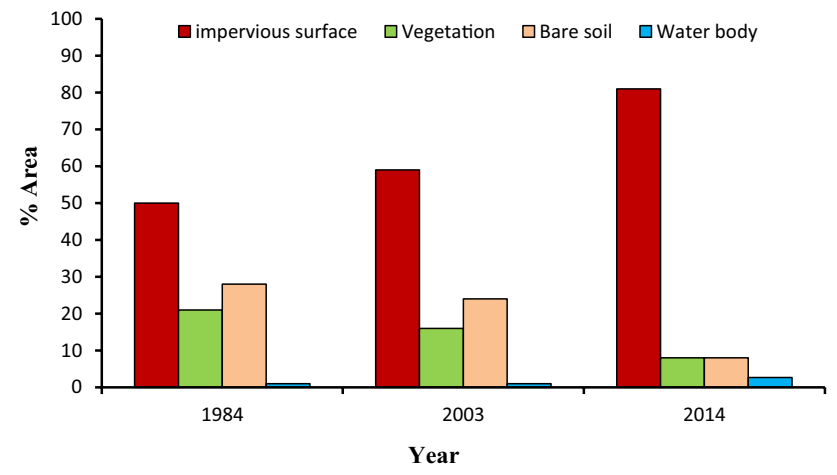

Fig. 4 Percentage area covered by land cover types over Abeokuta

to $56.83 \mathrm{~km}^{2}$ by 2014 . This is an indication of total transformation and urban development over Abeokuta area. Furthermore, water bodies were also slightly expanded from $0.88 \mathrm{~km}^{2}$ in 1984 to $2.09 \mathrm{~km}^{2}$ by 2014 due to probably increase in the extent of river Lafenwa in Abeokuta area.

The absolute land cover changes between 1984 and 2003, and 2003-2014 over Abeokuta area as described in Table 5 indicates that, vegetation and bare soil suffered losses between 1984 and 2014. In absolute term, a total proportion of 8.99 and $24.26 \%$ of both the vegetated and bare soil areas were lost during the nineteen-year and sixteen-year periods respectively. These losses also translated into increase in the amount of imperviousness over the area.

The structure of the vegetation and bare soil in Abeokuta area can be postulated as rapidly changing because of human/anthropogenic activities and extension of the urban core to the rural areas. These activities include but not limited to housing development, industrial, commercial, and recreational activities.

\section{Quantitative relationships among urban surface biophysical components}

Surface temperature has been established as a major indicator of the presence of surface urban heat island in cities and urban areas. The relationship between land cover and surface temperature was analyzed by producing the LST maps from the acquired landsat imageries. For each analyzed year, an image was produced that provided a visual
Fig. 5 Gains and Losses in Land cover areas between a 1984 and 2003 b 2003 and 2014. c 1984 and 2014

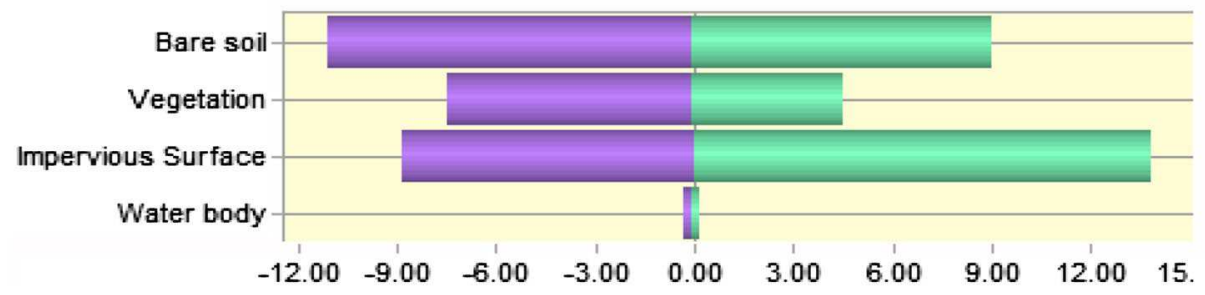

(a)

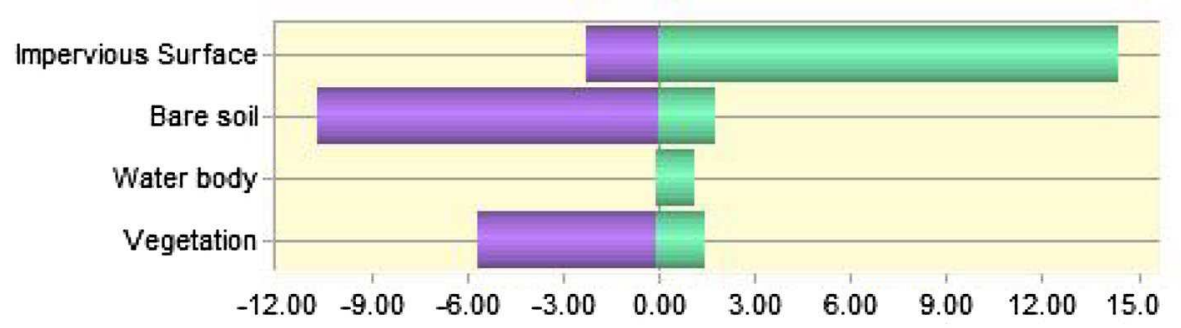

(b)

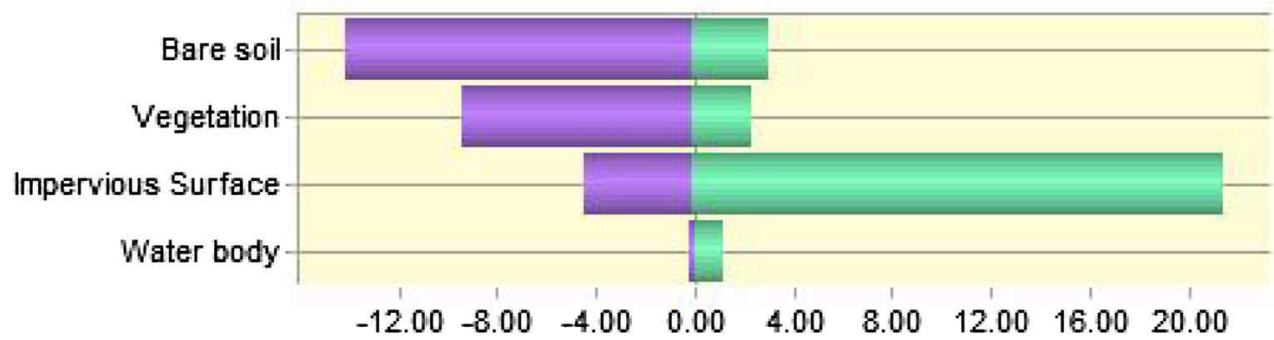

(c) 
Fig. 6 Net change in land cover areas between a 1984 and 2003 b 2003 and 2014 c 1984 and 2014

Fig. 7 Contributions to net change in impervious surface areas between $\mathbf{a} 1984$ and 2003 b 2003 and 2014 c 1984 and 2014

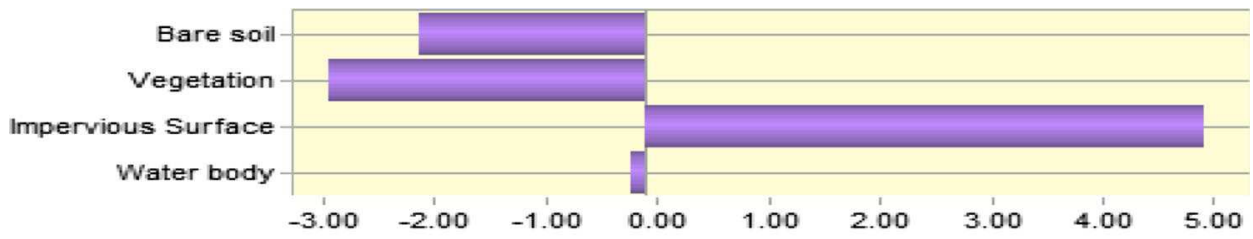

(a)

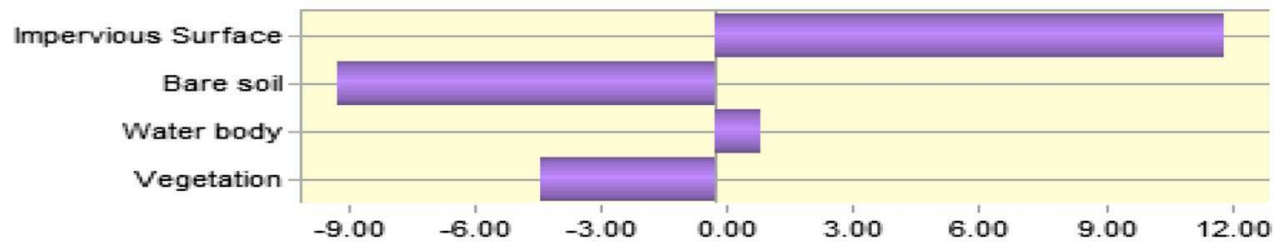

(b)

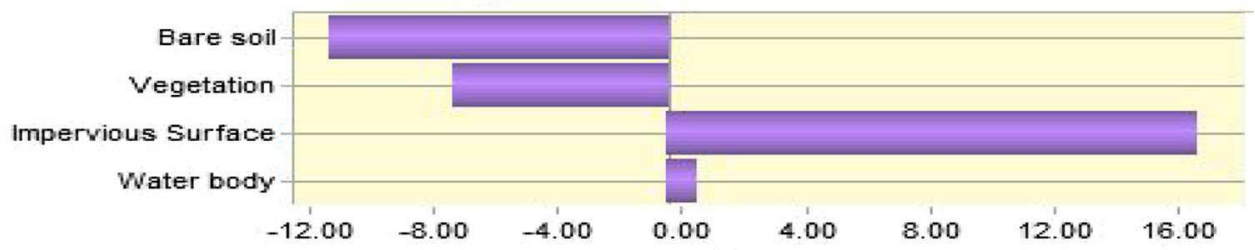

(c)

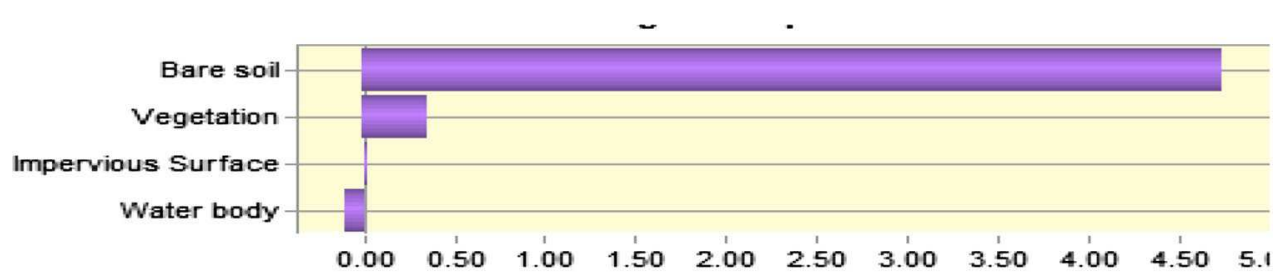

(a)

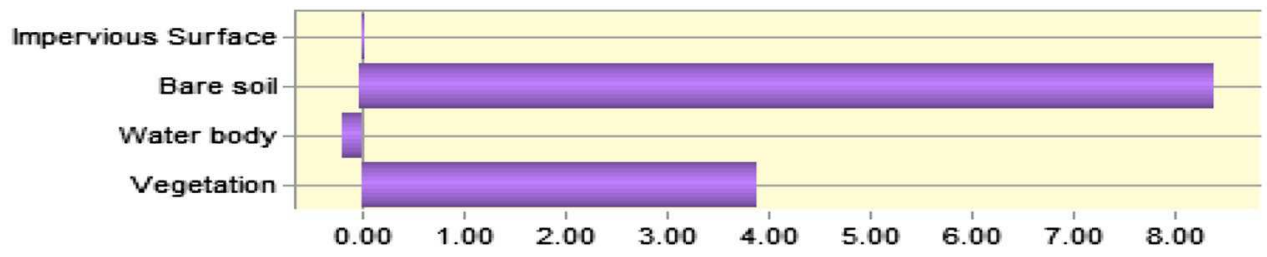

(b)

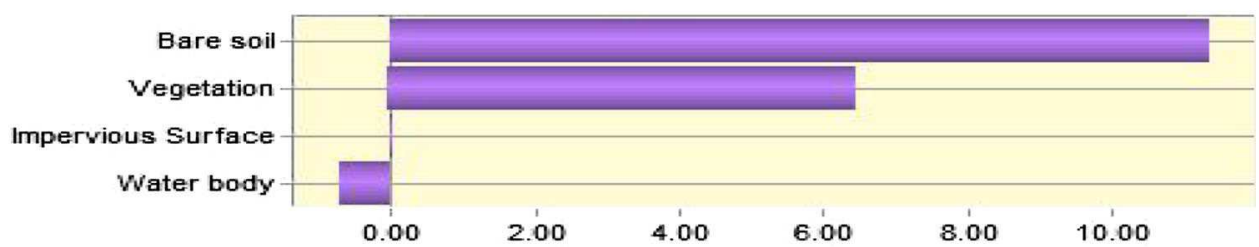

(c) resource for analyzing the intensity and spatiality of LST change.

The patterns of LST changes over Abeokuta area in the three time periods (Fig. 10) showed that, the LSTs ranged from 25.0 to $37.9{ }^{\circ} \mathrm{C}, 18.6$ to $34.4^{\circ} \mathrm{C}$ and 23.7 to $40.2{ }^{\circ} \mathrm{C}$ in 1984, 2003, and 2014 respectively. Figure 11a showed that no areas in Abeokuta experienced an extreme temperature $\left(\geq 41^{\circ} \mathrm{C}\right)$ as at the time satellite over-passed in 
Fig. 8 Contributions to net change in bare areas between a1984 and 2003 b 2003 and 2014 c 1984 and 2014

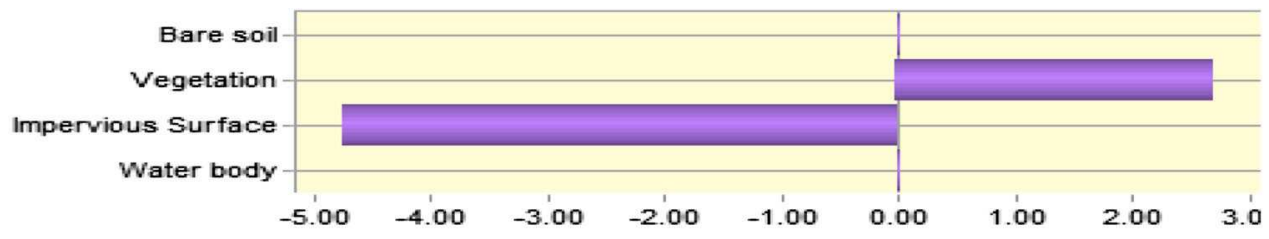

(a)

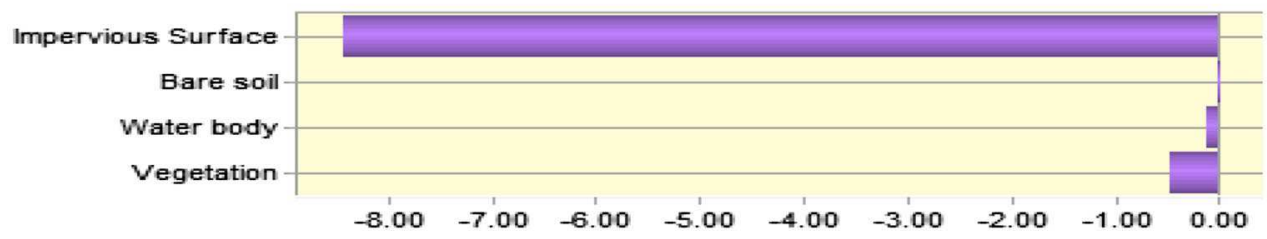

(b)

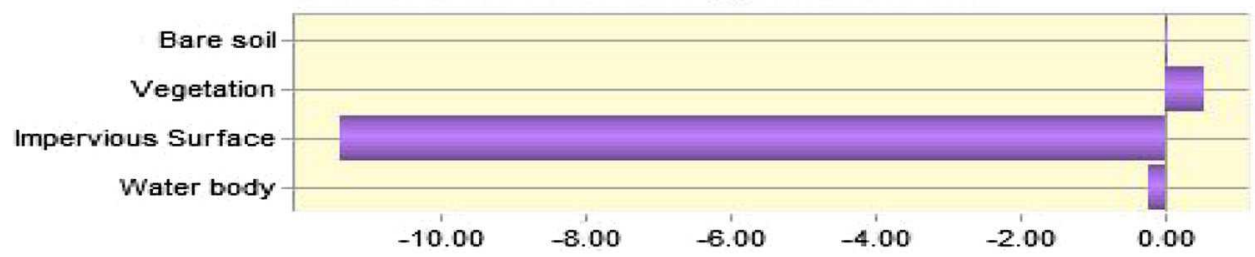

(c)

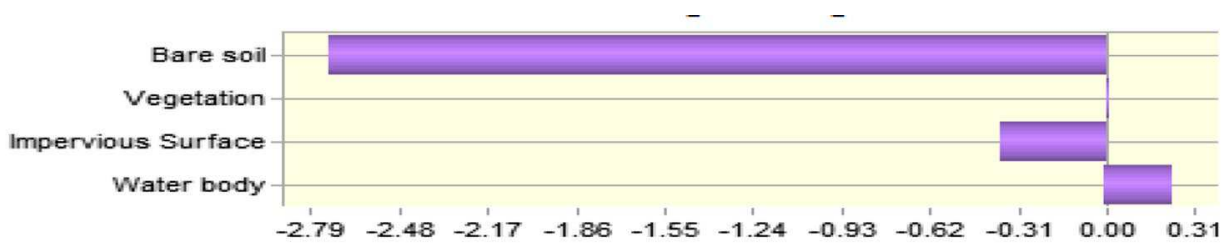

(a)

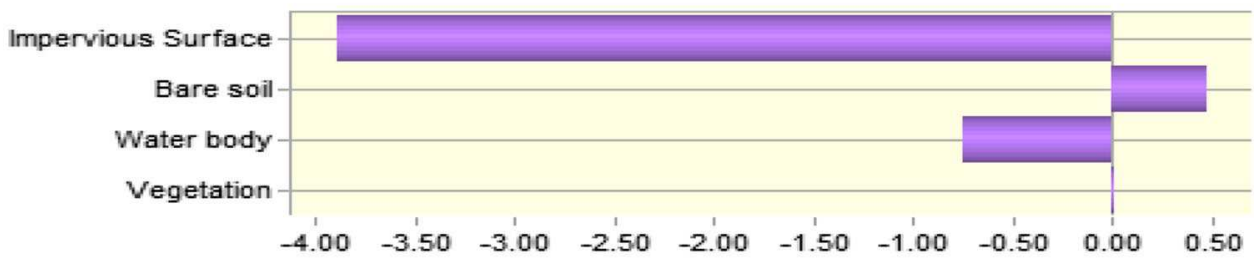

(b)

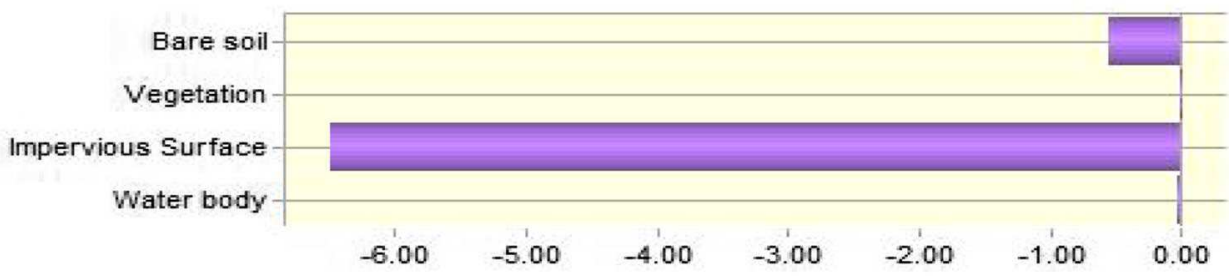

(c) all the periods. In 1984, a large part of the area $(67.7 \%$ in all) fell within the higher temperature zones $\left(\geq 30^{\circ} \mathrm{C}\right)$ and other areas $(32.3 \%)$ fell into mid temperature zones $\left(25^{\circ} \mathrm{C}\right.$ to $<30^{\circ} \mathrm{C}$ ). This high surface temperature might be due to high insolation as at the time satellite over passed, large distribution of imperviousness, or geographical relief of the area. But in 2003, about $66.3 \%$ proportions of the surface area were dominated by mid-surface temperature zones $\left(25^{\circ} \mathrm{C}\right.$ to $\left.<30^{\circ} \mathrm{C}\right)$. Other surface areas $(29.1 \%)$ and $(4.6 \%)$ fell in the lower $\left(<25^{\circ} \mathrm{C}\right)$ and higher $\left(\geq 30^{\circ} \mathrm{C}\right)$ temperature 
Table 5 Size and proportion, trend, and magnitude of LULC of Abeokuta area from 1984 to 2014

\begin{tabular}{|c|c|c|c|c|c|c|c|c|}
\hline \multirow[t]{2}{*}{ Land cover type } & \multicolumn{2}{|l|}{1984} & \multicolumn{2}{|l|}{2003} & \multicolumn{2}{|l|}{2014} & \multirow{2}{*}{$\begin{array}{l}183-2003 \\
\%\end{array}$} & \multirow{2}{*}{$\begin{array}{l}2003-2014 \\
\%\end{array}$} \\
\hline & $\left(\mathrm{km}^{2}\right)$ & $\%$ & $\left(\mathrm{~km}^{2}\right)$ & $\%$ & $\left(\mathrm{~km}^{2}\right)$ & $\%$ & & \\
\hline Impervious Surface & 34.84 & 50 & 41.29 & 59 & 56.83 & 81 & 9 & 22 \\
\hline Bare soil & 19.49 & 28 & 16.89 & 24 & 5.30 & 8 & -4 & -16 \\
\hline Vegetation & 14.53 & 21 & 10.86 & 16 & 5.52 & 8 & -5 & -8 \\
\hline Water & 0.88 & 1 & 0.70 & 1 & 2.09 & 3 & 0 & 2 \\
\hline Total & 69.74 & 100 & 69.74 & 100 & 69.74 & 100 & Not appicable & \\
\hline
\end{tabular}
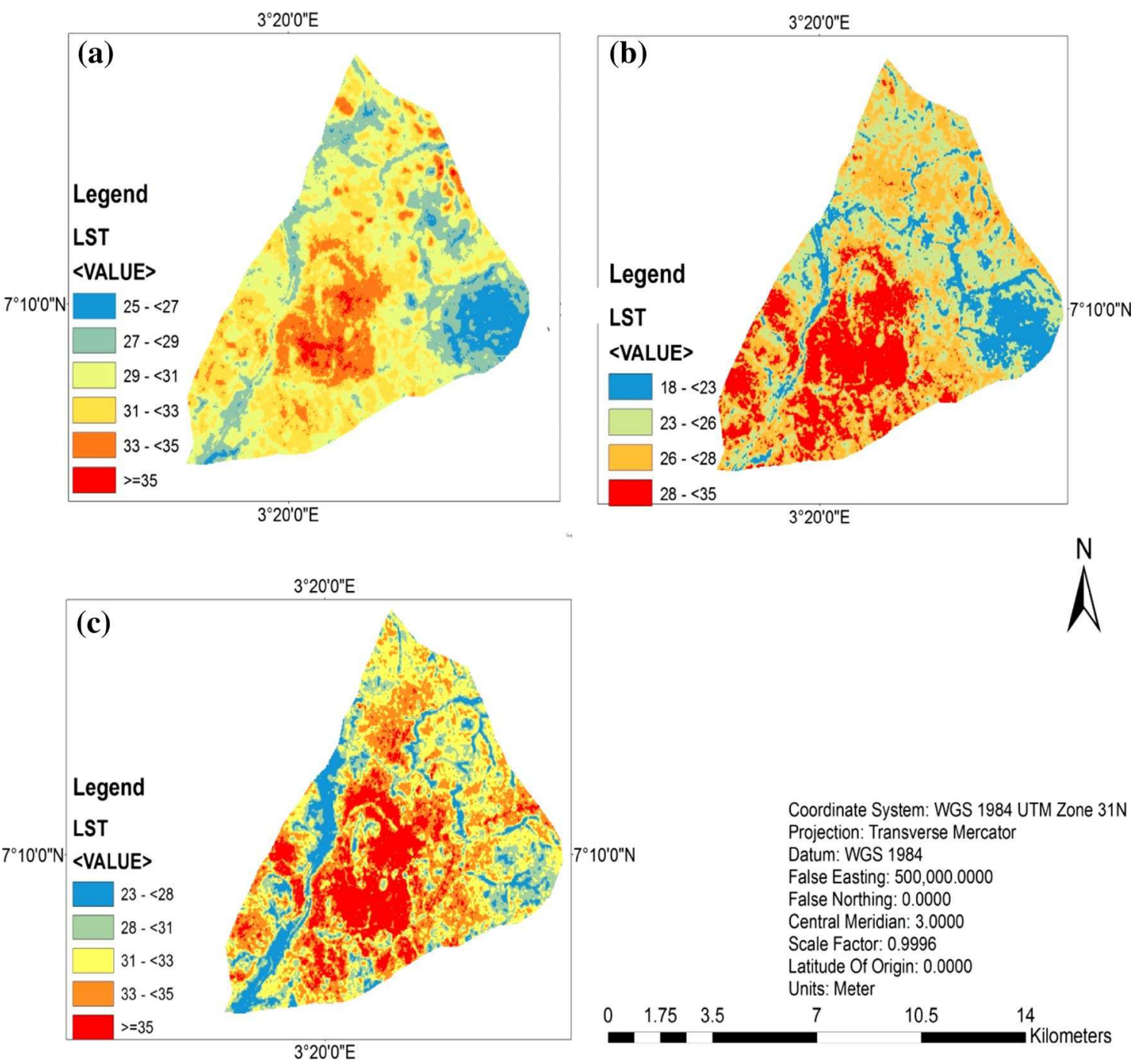

Fig. 10 Maps of Abeokuta city showing the thermal zones for a 1984 b 2003 c 2014

zones respectively. Moreover, a higher LST zone $\left(\geq 30^{\circ} \mathrm{C}\right)$ was also observed in majority $(81.6 \%)$ of the area in 2014 . A noticeable surface area proportion $(0.3 \%)$ and $(18.2 \%)$ were found in the lower $\left(<25^{\circ} \mathrm{C}\right)$ and $\operatorname{mid}\left(25^{\circ} \mathrm{C}\right.$ to $\left.<30^{\circ} \mathrm{C}\right)$ temperature zones respectively (Fig. 11a).

The mean surface temperature variation over different land cover types (Fig. 11b) showed that the majority of the bare soil and impervious surface areas of Abeokuta had temperatures between 32 and $35^{\circ} \mathrm{C}$ in both 1984 and 2014. In 2003, the temperature was cooler between 26 and $29^{\circ} \mathrm{C}$ in both land cover types. However, vegetation and water bodies have similar temperature variations between 28 and $30^{\circ} \mathrm{C}$ in 1984 and 2014. Moreover, the mean LSTs of vegetation cover and water bodies were taken to between 
Fig. 11 a Changing pattern of surface temperature zones; $\mathbf{b}$ Mean LST variations over different land cover types
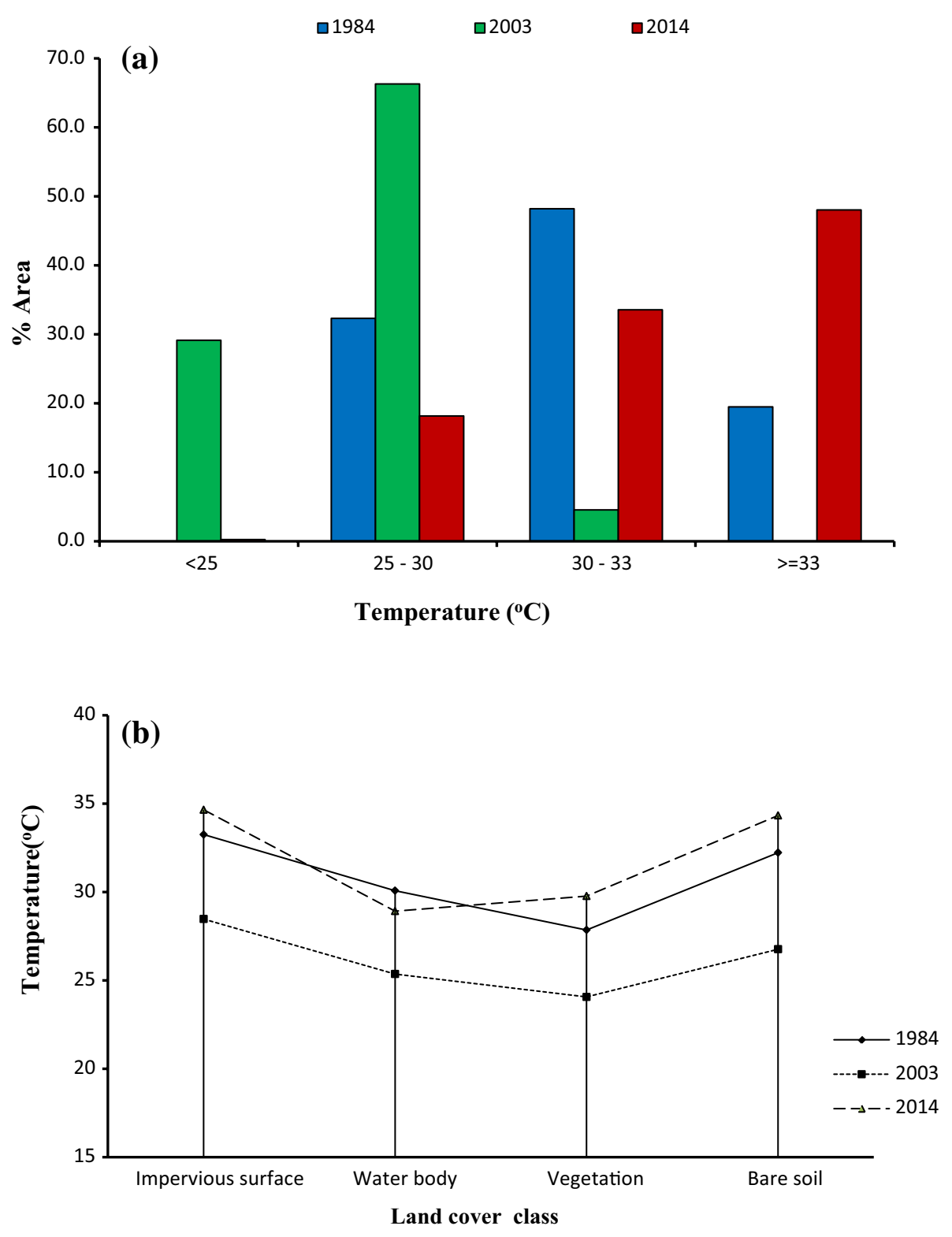

24 and $26^{\circ} \mathrm{C}$ in 2003 . The high surface temperature even over vegetation cover in 2014 was as a result of more surface modifications, anthropogenic activities, little vegetation, and consequently little/no evapotranspiration. In addition, the magnitude of LST change is almost the same (5-6 ${ }^{\circ} \mathrm{C} / 16$ 19years) over both impervious surface and bare soil (Fig. 11b).

The quantitative assessment of the relationship between the thermal zones and land cover types revealed that, the higher positive correlations were found between the ranges of temperature $<25^{\circ} \mathrm{C}$ and $25-<30^{\circ} \mathrm{C}$, and high temperature of $30-<33{ }^{\circ} \mathrm{C}$ and $\geq 33^{\circ} \mathrm{C}$. The highest negative correlations were found between the temperature range of $<25^{\circ} \mathrm{C}$ and $30-<33^{\circ} \mathrm{C}$ and the higher temperature ranges $\left(25-<30^{\circ} \mathrm{C}\right.$ and $\geq 33^{\circ} \mathrm{C}$ ) (Fig. 12). A high negative correlation was also found between the $25-<30^{\circ} \mathrm{C}$ and $30-<33{ }^{\circ} \mathrm{C}$ temperature range and the size of water bodies. The higher positive correlation between land covers was found between areas of vegetation and bare soil, and high correlation between impervious surface area (ISA) and water bodies. The highest negative correlation was between ISA and vegetated, and ISA and bare areas.

The best highest positive correlations were found between water/ISA areas and temperatures $\geq 33^{\circ} \mathrm{C}$.

These findings were consistent with the study from Yuan and Bauer (2007). Other positive correlations were found between bare areas and temperatures between 25 and $<30^{\circ} \mathrm{C}$. However, these correlations were not as high compared to what was found in ISA/water areas. The highest positive correlations with low temperatures were found 
Fig. 12 Correlations among LSTs and land cover types

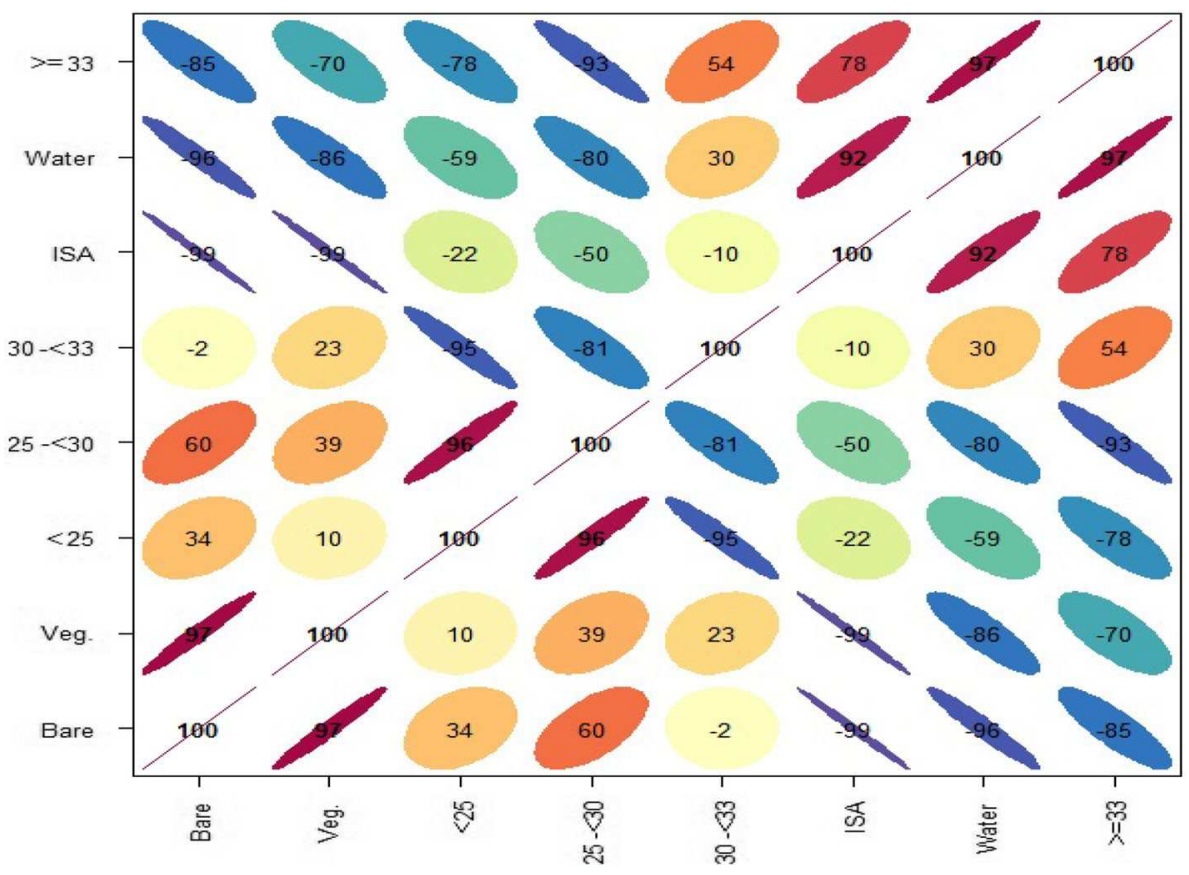

in the classes of bare soil and vegetation. Conversely, vegetation and bare areas had a high negative correlation with high temperatures. As shown in Figs. 3, 11a and 12, changes in land cover patterns are highly correlated to changes in LSTs and the SUHI effect.

The impervious surface and water areas were found to contribute positively to LST rise (Fig. 12). Consequently, this might lead to SUHI effect because the growth of impervious surfaces coincided with an increase in temperatures. However, Vegetation and bare areas contributed negatively to SUHI effect.

\section{Surface temperature change and the effectiveness of surface biophysical indices}

\section{Quantitative relationship among surface biophysical indices and temperature}

The impacts of the surface biophysical components on surface temperature were further evaluated in a more robust way using the surface biophysical indices. The results from the analysis showed that, the highest positive correlation among land cover indices was found between NDBI and SSR.

Figure 13 shows that NDBI ranged between -0.24 and $+0.14,-0.26$ and +0.20 , and -0.33 and +0.26 in 1984, 2003, and 2014 respectively. Unlike NDVI, a higher NDBI values show the high density built-up areas, while a lower NDBI values indicate vegetation and other surfaces. It was observed that the NDBI values have increased over the periods suggesting that the built-up area has risen. The findings show an evolution of urban expansion in Abeokuta based on the increasing NDBI values over time. Several studies have been carried out to quantify SSR over different land cover types.

Table 3 shows the range of SSR values for different surfaces. The results from SSR maps produced over Abeokuta area (Fig. 14) showed that, SSR has values ranged from 0.18 to 0.24 in $1984,0.17$ to 0.26 in 2003 , and 0.14 to 0.28 in 2014. In comparison with respective land cover maps (Fig. 3), it was observed that, the highest SSR between 0.22 and 0.25 was experienced over bare soil areas, while water bodies fall in the lowest SSR range (between 0.16 and 0.19) in all the periods (Fig. 14). These results suggest that, the various surface features categorized as bare soil tend to absorb heat quickly than other land cover types in Abeokuta area. This implies that high surface temperatures were experienced over bare soil in all the periods (Fig. 11b) due to its high heat capacity. In addition, the SSR values in Abeokuta, and in all periods fall between 0 and 0.35 , which is in accordance with the expected range of values over these areas according to reference values in Table 3.

The highest negative correlation was found between NDISI and SSR (Fig. 15). To relate the land cover indices to LSTs, we analyzed the correlations among the various indices and LST. The best highest positive correlation of 0.72 was found between NDBI and LST. Other positive correlation of 0.58 was found between surface reflectivity and temperatures. However, both NDISI and NDVI are negatively correlated with LST. NDVI had the higher negative correlation of 0.70 with LST in the area (Fig. 15). 

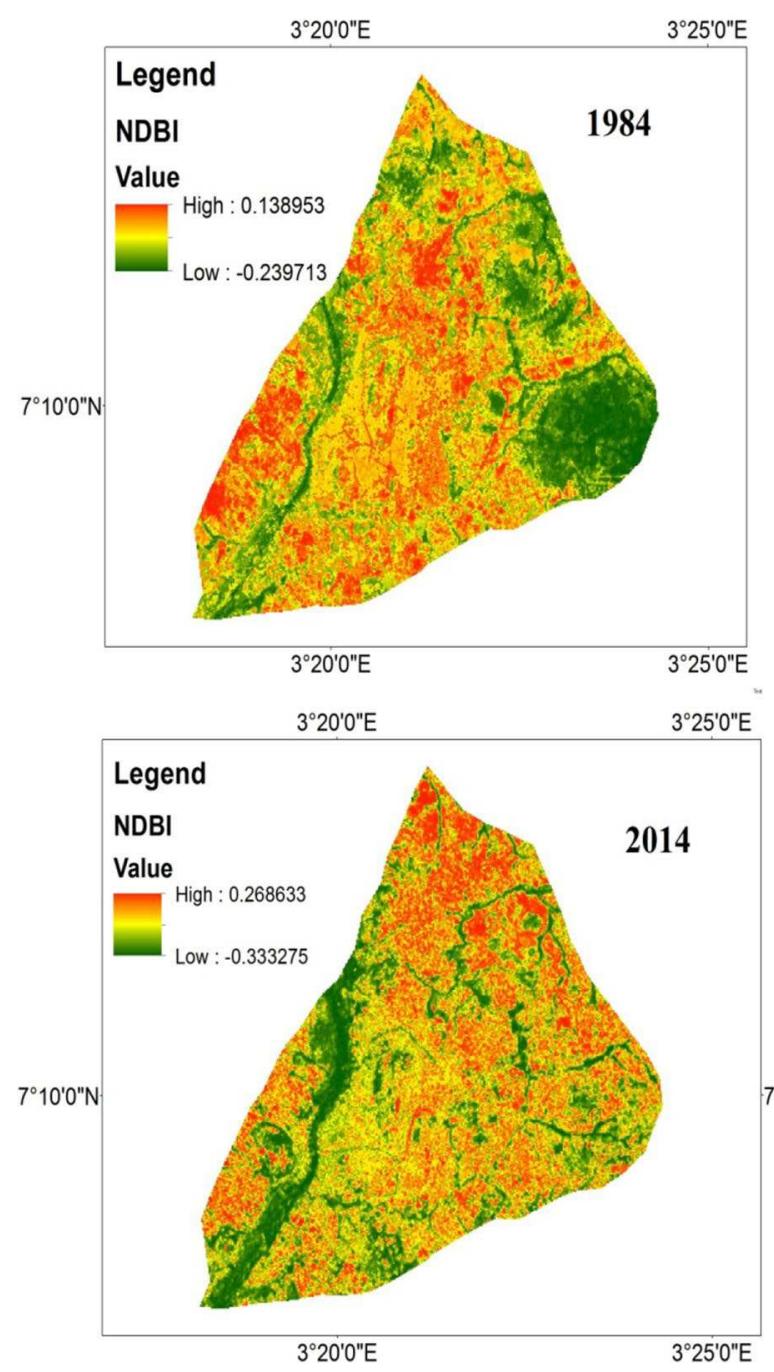
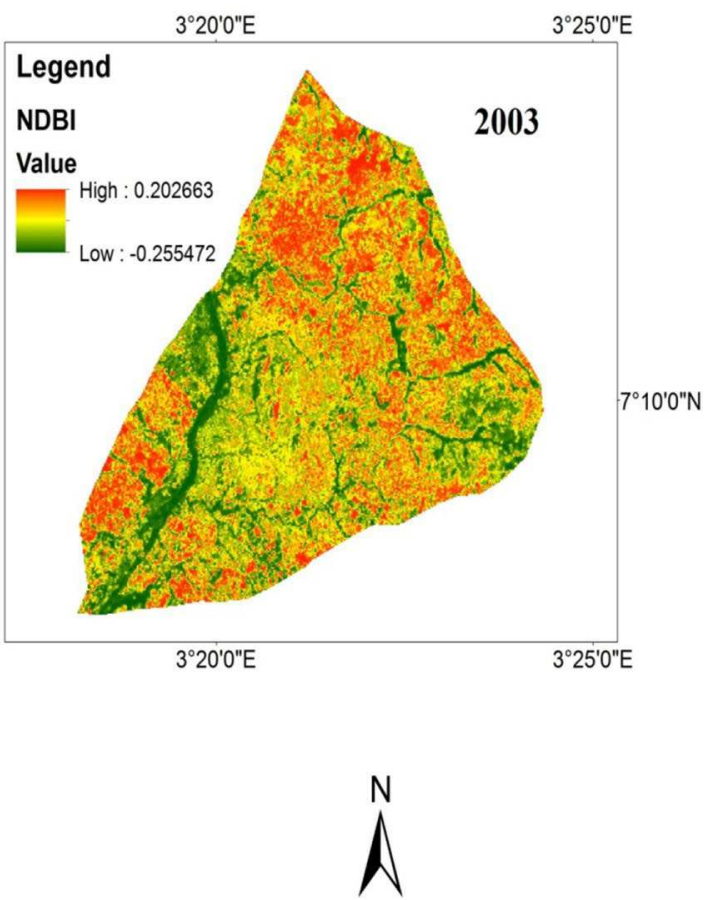

Coordinate System: WGS 1984 UTM Zone 31N Projection: Transverse Mercator Datum: WGS 1984

False Easting: $500,000.0000$

False Northing: 0.0000

Central Meridian: 3.0000

Scale Factor: 0.9996

Latitude Of Origin: 0.0000

Units: Meter

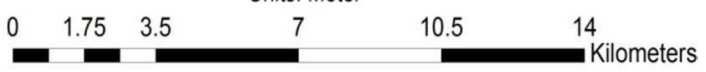

Fig. 13 Spatial distribution of NDBI over Abeokuta

This result showed the relationship between the land cover indices and LST. As illustrated in the Fig. 15, changes in land cover indices are highly correlated to changes in LSTs over the study area. Therefore, it can be deduced that NDVI behaves inversely to other biophysical indices especially NDBI, SSR, and LST (Zhang et al. 2009; Zeng et al. 2010; Musa et al. 2012; Ibrahim et al. 2012). Thus, it can be used as an indicator to ameliorating the effect of surface urban heat in the area. Although the correlation results between the indices and LSTs showed a good relationship, further analysis was carried out using indices as predictors to LST change. The results using different stepwise regression models (such as linear, polynomial, exponential, and power) produced the statistical output shown in Table 6.

The summary output (Table 6) indicates that, the land cover indices except NDVI are all retained during the stepwise regression procedures. Of the four regression models, the exponential model achieves the highest correlation value (significant at 0.01 level) in Abeokuta area. It was observed that, the relationships of NDBI, NDISI, SSR, and LST are not simple linear but rather exponential. This suggests that, the land cover indices have separate positive contributions to LST change. Thus, they are all important factors in modulating urban temperature in Abeokuta area.

Figure 16 shows percentage contributions of each spectral index to LST change. The major contributors to LST change in Abeokuta are both NDBI and SSR with 51.3 and $32.7 \%$ respectively. There is little or no significant contributions from NDVI and \%NDISI to LST change in this area. Basically, it is deduced that both NDBI and SSR explain most of the LST variations over the whole study area. This is probably due to increasing built-up and low reflective materials in the area. Thus, NDBI and SSR are effective indicators to change in surface temperature over Abeokuta area. 

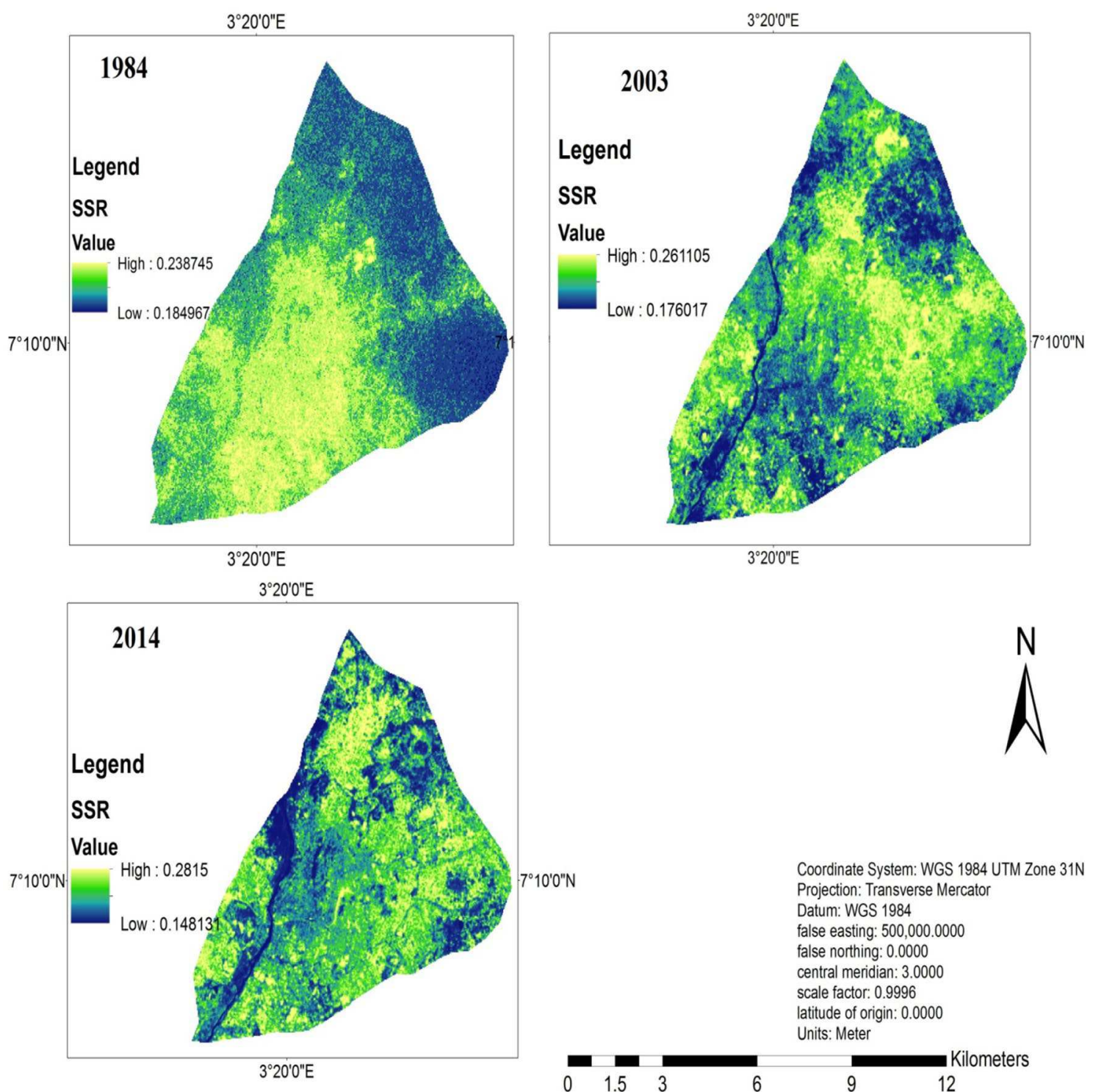

Fig. 14 Spatial distribution of SSR over Abeokuta

\section{Regression model-based estimation of surface temperature}

Accordingly, surface temperature for each pixel sample was estimated over the study area using the spectral indicesbased regression model. The estimated LSTs for the area was presented as gridded map (Fig. 17).

The result (Fig. 17) showed that the estimated LSTs have similar spatial variations with the landsat retrieved LSTs over the whole area. It was observed that pixels with lower LSTs (with leaf green tone) were found in non-developed areas, in which surface features categorized as vegetation are dominant land covers. However, pixels with higher LST (displayed with light grey to white tone) are in developed areas categorized as impervious surfaces. Besides, pixels in residential areas where vegetation was mixed with different manmade materials were shown in a brown to dark yellow tone, indicating the existence of medium LSTs. Temperature difference maps (Fig. 18) and scatterplots (Fig. 19) between the estimated and retrieved LST values also indicated a satisfactory estimation with regression models. The estimated LST and retrieved LST showed positive correlation from a moderate regression of 0.659 in Abeokuta (Fig. 19). Furthermore, Fig. 18 indicates that there is a large variation of LST over developing areas of Abeokuta with the core at the areas mixed with vegetation and artificial materials. 


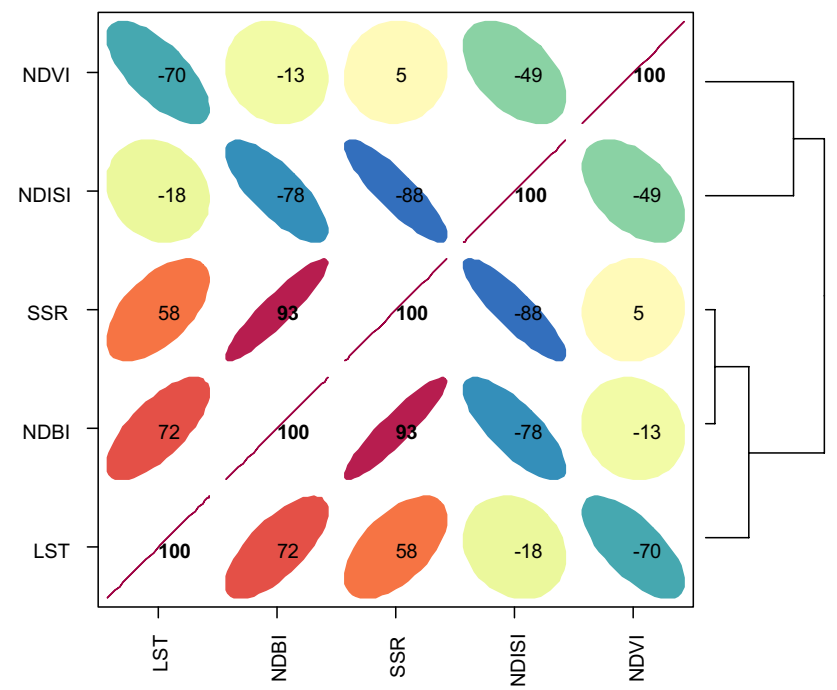

Fig. 15 Correlation matrix of mean LST and surface biophysical indices over Abeokuta

Table 6 Statistical summary output of Abeokuta $\left(\mathrm{LST}=e^{0.3+1.2 N D B I+}\right.$ $0.04 \% N D I S I+5.2 S S R)\left(\mathrm{R}^{2}=0.945\right)$

\begin{tabular}{lllll}
\hline & Coefficients & Standard error & $t$ value & $p$ value \\
\hline Intercept & 0.30 & 0.71 & 0.43 & 0.68 \\
NDBI & 1.20 & 0.26 & 4.63 & 0.00 \\
NDISI & 0.04 & 0.01 & 4.23 & 0.00 \\
NDVI & 0.78 & 0.42 & 1.86 & 0.08 \\
SSR & 5.23 & 1.08 & 4.83 & 0.00 \\
\hline
\end{tabular}

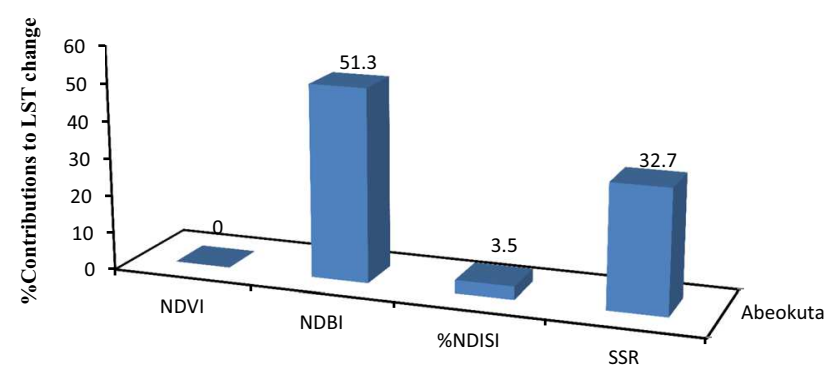

Fig. 16 Separate contributions of surface biophysical indices to LST change in the study area

\section{Comparative analysis and accuracy assessment}

The estimated LST when compared with the retrieved LST image (Fig. 20), the estimated image has a similar overall spatial pattern. Specifically, sample values with lower LSTs were found in vegetated areas. Comparatively, sample values with higher LST are in impervious surface areas. Besides, sample values where vegetation was mixed with other land cover types (e.g. bare soil) indicate the existence of medium LSTs over the whole study area. The results of accuracy measurements also verified the similarity between the regression-modeled LST and the retrieved LST (see Table 7). Table 7 indicates that the overall error for the study area is quite low, $2.63{ }^{\circ} \mathrm{C}$ for RMSE and $2.17^{\circ} \mathrm{C}$ for MAE. Furthermore, it also shows that higher RMSEs and MAEs are found in the in less-developed areas of Abeokuta. However, developed areas of Abeokuta showed lower RMSEs and MAEs. This observation could be probably due to the larger variations of thermal properties of different surfaces with various anthropogenic materials than those of natural materials dominated by vegetation.

Visual comparisons over Abeokuta (Fig. 20) indicate that the spectral indices-based regression model slightly overestimate LSTs in developed lands, such as commercial, residential, and transportation land uses, etc., and significantly underestimate LSTs in under-developed. This is probably due to the less impacts of surface biophysical characteristics on LST in under-developed. Moreover, It also shows that the performance of this model is relatively well in developed areas, but poor in the under-developed areas of Abeokuta. This is probably due to the nonlinear relationship between land cover indices and LST.

\section{Conclusions}

This study has been able to address and provide vital information on the changes of urban surface biophysical components through the qualitative and quantitative analyses performed to assess the status of urban surface components and the relationship between surface biophysical changes and thermal response over Abeokuta city, Nigeria. This study has proven that the modification of the natural surface is the main driver of land cover changes and consequently LST, especially in rapid urbanizing cities like Abeokuta in Nigeria. This is attributed to the compelling socio-economic factors such as rural-urban migration, the demand for space as a result of increasing population, and lack of urban monitoring and planning. However, the research has indicated that the possibility of further urbanization process in Abeokuta area cannot be ruled out because of its projected industrial and institutional opportunities (Ahmed 2011) due to the recent rapid socio-economic development. Hence, the susceptible areas to urbanization process should be decentralized in order to prevent the formation of largescale urban heat effect in the future. Additional consideration to plan and implement the concepts of urban greening would also help reducing the LST in the area (Kibert 2012). Finally, further research should seek to extend the study area by incorporating the rural/ less urbanized surroundings of the region in order to simulate surface urban heat effect in the future context. 
Fig. 17 LST estimates generated from surface biophysical indices-based regression models
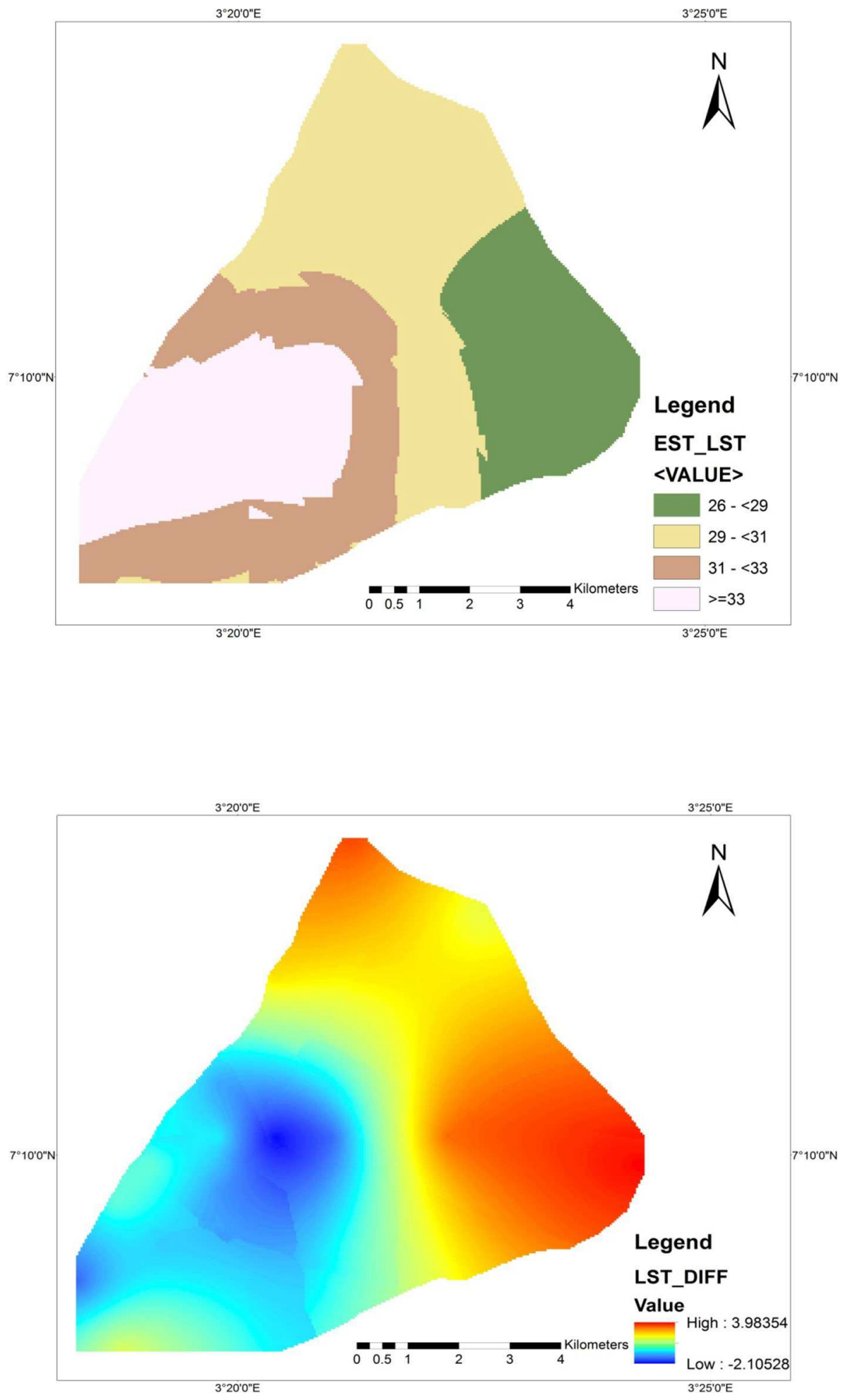

Fig. 18 Maps of LST Difference (subtraction of the retrieved LST from modeled LST) 


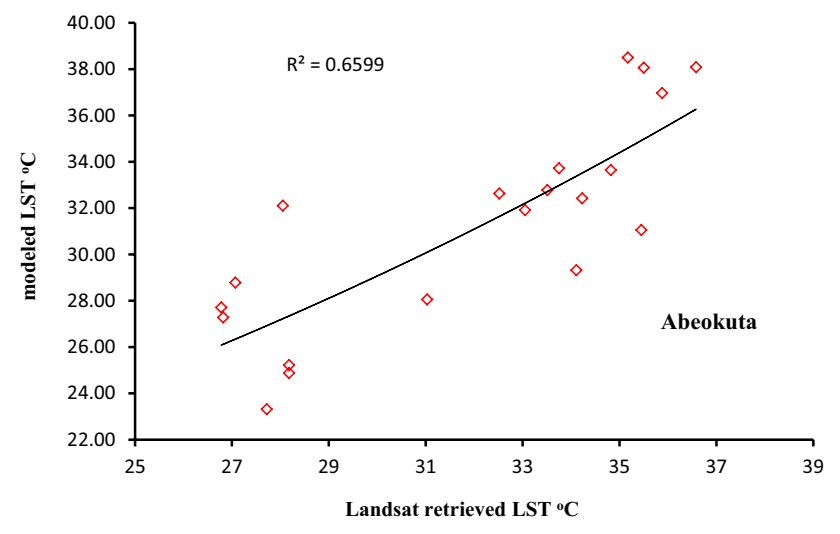

Fig. 19 Scatterplot of the retrieved LST and estimated LST for the study area

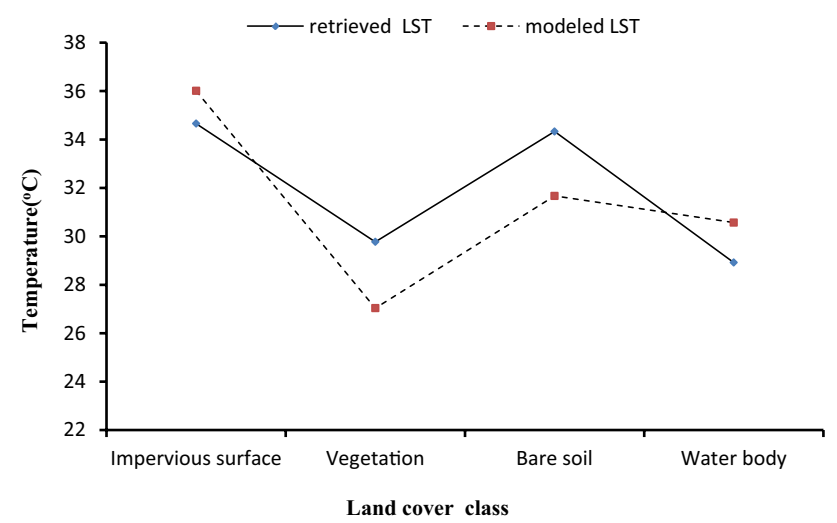

Fig. 20 Comparative patterns of retrieved LST and modeled LST over Abeokuta

Table 7 Accuracy measures of different models based on the Landcover types and spectral indicators

\begin{tabular}{lll}
\hline Metric & Land cover type & $\begin{array}{l}\text { Regression model } \\
\text { Abeokuta }\left({ }^{\circ} \mathrm{C}\right)\end{array}$ \\
\hline RMSE & Impervious surface & 2.02 \\
& Vegetation & 3.09 \\
& Bare soil & 3.11 \\
& Water & 2.08 \\
& Overall & 2.63 \\
MAE & Impervious surface & 1.65 \\
& Vegetation & 2.73 \\
& Bare soil & 2.66 \\
& Water & 1.65 \\
& Overall & 2.17 \\
\hline
\end{tabular}

Acknowledgements The authors thank the United States Geological Survey (USGS) for assisting this research with datasets, and as well as the developers of SEBAL algorithms used in computations.

\section{References}

Adedeji OH, Tope-Ajayi OO, Abegunde OL (2015) Assessing and predicting changes in the status of Gambari Forest Reserve, Nigeria using remote sensing techniques. J Geogr Inform Syst 7:301-318. doi:10.4236/jgis.2015.73024

Adeniyi PO, Omojola A (1999) Landuse/landcover change evaluation in sokoto-rima basin of North-Western Nigeria on archival remote sensing and GIS techniques. J Afr Assoc Remote Sens Environ (AARSE) 1: 142-146

Ahmed B (2011) Urban land cover change detection analysis and modeling spatio-temporal growth dynamics using remote sensing and GIS techniques: a case study of Dhaka, Bangladesh. Master's thesis, erasmus mundus program. Universidade Nova de Lisboa (UNL), Instituto Superior de Estatística e Gestão de Informação (ISEGI), Lisbon, Portugal

Ahmed B, Ahmed R (2012) Modeling urban land cover growth dynamics using multi-temporal satellite images: a case study of Dhaka, Bangladesh. ISPRS Int J Geo-Inf 1:3-31

Ahmed B, Kamruzzaman Md, Zhu X, Rahman MdS, Choi K (2013) Simulating land cover changes and their impacts on land surface temperature in Dhaka, Bangladesh. J Remote Sens 5:5969-5998. doi:10.3390/rs5115969

Bastiaanssen, WGM, Menenti M, Feddes RA, Holtslag AAM (1998) A remote sensing surface energy balance algorithm for land (SEBAL). Part 1: Formulation. J Hydrol 212-213:198-212

Brutsaert W (1982) Evaporation into the atmosphere. D. Reidel Publishing Co., Dordrecht p 300

Chander G, Markham B (2003) Revised landsat-5 TM radiometric calibration procedures and postcalibration dynamic ranges. IEEE Trans Geosci Remote Sens 41(11):2674-2677

Chandler TJ (1976) Urban climatology and its relevance to urban design. WMO technical note No. 149,WMO N0.438. World Meteorological Organization, Geneva

Chudnovsky A, Ben-Dor E, Saaroni H (2004) Diurnal thermal behaviour of selected urban objects using remote sensing measurements. Energy Build 36:1063-1074. doi:10.1016/j. enbuild.2004.01.052

Congalton RG (1991) A review of assessing the accuracy of classifications of remotely sensed data. Remote Sens Environ 37:35-46

Deng JS, Wang K, Hong Y, Qi JG (2009) Spatio-temporal dynamics and evolution of land use change and landscape pattern in response to rapid urbanization. Landsc Urban Plan 92:187-198. doi:10.1016/j.landurbplan.2009.05.001

Dousset B, Gourmelon F (2003) Satellite multi-sensor data analysis of urban surface temperatures and land cover. ISPRS J Photogr Remote Sens 58:43-54

Eastman, J.R. (2006) IDRISI andes guide to GIS and image processing, worcester, clark labs. Environmental systems research institute (ESRI): Redlands, CA, USA, 2012. ArcGIS® 10 Help. http://help.arcgis.com/en/arcgisdesktop/10.0/help/. Accessed 15 Jan 2015

Friedl MA (2002) Forward and inverse modeling of land surface energy balance using surface temperature measurements. Remote Sens Environ 79:344-354

Ibrahim I, Samah AA, Fauzi R (2012) Land surface temperature and biophysical factors in urban planning. In: International conference on ecosystem, environment and sustainable development, Kuala Lumpur, Malaysia, vol 68. World Academy of Science, Engineering and Technology, pp 1792-1797 
IDRISI (2006) IDRISI andes: guide to GIS and image processing. clark labs, Clark University, Worcester. http://www.cartografia. cl/download/manuales/idrisi_andes.pdf. Accessed 15 Jan 2015

Igor O, Bastos VSB (2012) A quantitative approach for analyzing the relationship between urban heat islands and land cover. $\mathrm{J}$ of Remote Sens 4:35963618. doi:10.3390/rs4113596

Jennings MD (2000) Gap analysis: concepts, methods, and recent results. Landscape Ecol 15:5-20. doi:10.1023/A:1008184408300

Jensen JR (2000) Remote sensing of the environment: an earth resource perspective. Prentice Hall, Upper Saddle River, p 544

Jensen JR (2007) Remote sensing of the environment: an earth resource perspective. 2nd edn Pearson Prentice Hall, Upper Saddle River

Kaufman YJ (1989) The atmospheric effect on remote sensing and its corrections. In: Asrar G (ed) Theory and applications of optical remote sensing. Wiley-Interscience, New York, pp 336-428

Kerr JT, Ostrovsky M (2003) From space to species: ecological applications for remote sensing. Trends Ecol Evol 18:299-305. doi:10.1016/S0169-5347(03)00071-5

Kibert CJ (2012) Sustainable construction: green building design and delivery, 3rd edn. Wiley, Hoboken, p 236

Lillesland MT, Kiefer R (1999) Remote sensing and image interpretation. 4th edn. Wiley, New York.

Loveland TR, Dwyer JL (2012) Landsat: building a strong future. Remote Sens Environ 122:22-29. doi:10.1016/j.rse.2011.09.022

Lu D, Weng Q (2006) Use of impervious surface in urban land use classification. Remote Sens Environ 102:146-160

Magidi JT (2010) Spatio-temporal dynamics in land use and habitat fragmentation in the sandveld, South Africa. MSc Thesis, Department of Biodiversity and Conservation Biology, University of the Western Cape, Western Cape

Mishra M, Mishra K, Subudhi A, Phil M (2011) Urban sprawl mapping and land use change analysis using remote sensing and gis: case study of Bhubaneswar City, Orissa. Proc Geo Spal World Forum Hyderabad 18-21

Musa J, Bako MM, Yunusa MB, Garba IK, Adamu M (2012) An assessment of the impact of urban growth on land surface temperature in FCT, Abuja using geospatial technique. Sokoto J Soc Sci $2: 2$

Mussie O (2011) Bias in land cover change estimates due to misregistration. Int J Remote Sens 21:3553-3560

Nigeria Meteorological Agency (2007). Nigeria climate review bulletin. Nigeria Met. Agency No 001

Odindi J, Mhangara P, Kakembo V (2012) Remote sensing land-cover change in port elizabeth during South Africa's democratic transition. S Afr J Sci 108:1-7. doi:10.4102/sajs.v108i5/6.886

Oke TA (1982) The energetic basis of the urban heat island. Quart J Royal Meteor Soc 108:124

Pellikka PKE, Lotjonen M, Sijander M, Lens L (2009) Airborne remote sensing of spatiotemporal change (1955-2004) in indigenous and exotic forest cover in the Taita Hills, Kenya. Int J Appl Earth Obs Geoinf 11:221-232. doi:10.1016/j.jag.2009.02.002

Quattrochi DA, Pelletier RE (1991) Remote sensing for analysis of landscapes: an introduction quantitative methods in landscape ecology. The analysis and interpretation of landscape heterogeneity, Turner MG, Gardner RH (ed) Springer-Verlag, New York, pp. 51-76

R Development Core Team (2012) R: a language and environment for statistical computing; $r$ foundation for statistical computing: Vienna, Austria. http://www.R-project.org. Accessed 25 March 2015

Ralf W, Allen R, Tasumi M, Trezza R, Bastiaanssen W (2002) Surface energy balance algorithm for land (SEBAL) Idaho implementation. Adv Train Users Man Vers 1.0
Rogan J, Miller J (2006) Integrating GIS and remote sensing for mapping forest disturbance and change. In: Wulder MA, Franklin SE (ed), Understanding forest disturbance and spatial pattern: remote sensing and GIS approaches, CRC Press-Taylor and Francis, Boca Raton, 133-171. doi:10.1201/9781420005189.ch6

Sarrat C, Lemonsu A, Masson V, Guedalia D (2006) Impact of urban heat island on regional atmospheric pollution. Atmos Environ 40:1743-1758

Shoshany M, Aminov R, Goldreich Y (1994). The extraction of roof tops from thermal imagery for analyzing the urban heat island structure. Geocarto Int 4:61-69

Tasumi M, Allen RG, Bastiaanssen WGM (2000) The theoretical basis of SEBAL. Appendix A of Morse et al. Idaho Dep Water Resour Idaho

United Nations, Department of Economic and Social Affairs, Population Division (2006) World urbanization prospects: the 2005 revision, United Nations, New York

United States Geological Survey (USGS) (2014) New earth explorer. http://earthexplorer.usgs.gov. Accessed 18 Dec 2014

Voogt JA, Oke TR (2003) Thermal remote sensing of urban climate. Remote Sens Environ 86:370-384

Weng Q (2002) Land use change analysis in the Zhujiang Delta of China using satellite remote sensing, GIS and stochastic modelling. J Environ Manage 64:273-284. doi:10.1006/ jema.2001.0509

Weng Q, Lu D, Schubring J (2004) Estimation of land surface temperature-vegetation abundance relationship for urban heat island studies. Remote Sens Environ 89:467-483

Wu Q, Li H, Wang R, Paulussen J, Hec Y, Wang M, Wang B, Wang $\mathrm{Z}$ (2006) Monitoring and predicting land use change in Beijing using remote sensing and GIS. Landsc Urban Plan 78:322-333. doi:10.1016/j.landurbplan.2005.10.002

Wu B, Wang X, Shen H, Zhou X (2012) Feature selection based on max-min associated indices for classification of remotely sensed imagery. Int J Remote Sens 33(17-18):5492-5512

Xiao R-B, Ouyang Z-Y, Zheng H, Li W-F, Schienke EW, Wang X-K (2007) Spatial patterns of impervious surfaces and their impact on land surface temperature in Beijing, China. J Environ Sci $19: 250-256$

$\mathrm{Xu} \mathrm{H}$ (2010) Analysis of impervious surface and its impact on urban heat environment using the normalized difference impervious surface index (NDISI). Photogr Eng Remote Sens 76(5):557-565

Yuan F, Bauer M (2007) Comparison of impervious surface area and normalized difference vegetation index as indicators of surface urban heat island effects in Landsat imagery. Remote Sens Environ 106(3):375-386

Zemba AA (2010) Analysis of urban surface biophysical descriptors and land surface temperature variations in Jimeta city, Nigeria. Glob J Human Soc Sci 10 Iss 1(V.1.0):19-25

Zeng Y, Huang W, Zhan FB, Zhang H, Lue H (2010) Study on the Urban Heat Island (UHI) effects and its relationship with surface biophysical characteristics using MODIS imageries. Geo Spat Inf Sci 13(1):1-7 ID:1009-5020(2010)01-001-07

Zha Y, Gao Y, Ni S (2003) Use of normalized difference built-up index in automatically mapping urban areas from TM imagery. Int J Remote Sens 24:583-594

Zhang YS, Odeh Inakwu OA, Han CF (2009) Bitemporal characterization of land surface temperature in relation to impervious surface area, NDVI and NDBI, using a sub-pixel image analysis. Int J Appl Earth Obs Geoinf 11:256-264 